\title{
Impacts of future deforestation and climate change on the hydrology of the Amazon Basin: a multi-model analysis with a new set of land-cover change scenarios
}

\author{
Matthieu Guimberteau ${ }^{1}$, Philippe Ciais ${ }^{1}$, Agnès Ducharne ${ }^{2}$, Juan Pablo Boisier ${ }^{3}$, Ana Paula Dutra Aguiar ${ }^{4}$, \\ Hester Biemans $^{5}$, Hannes De Deurwaerder ${ }^{6}$, David Galbraith ${ }^{7}$, Bart Kruijt ${ }^{5}$, Fanny Langerwisch ${ }^{8}$, German Poveda $^{9}$, \\ Anja Rammig ${ }^{8,10}$, Daniel Andres Rodriguez ${ }^{11}$, Graciela Tejada ${ }^{4}$, Kirsten Thonicke ${ }^{8}$, Celso Von Randow ${ }^{4}$, \\ Rita C. S. Von Randow ${ }^{4}$, Ke Zhang ${ }^{12}$, and Hans Verbeeck ${ }^{6}$ \\ ${ }^{1}$ Laboratoire des Sciences du Climat et de l'Environnement, LSCE/IPSL, CEA-CNRS-UVSQ, Université Paris-Saclay, \\ 91191 Gif-sur-Yvette, France \\ ${ }^{2}$ Sorbonne Universités, UPMC, CNRS, EPHE - UMR7619 METIS, 75252 Paris, France \\ ${ }^{3}$ Department of Geophysics, Universidad de Chile, and Center for Climate and Resilience Research (CR2), Santiago, Chile \\ ${ }^{4}$ Centro de Ciência do Sistema Terrestre (CCST), Instituto Nacional de Pesquisas Espaciais (INPE), Av dos Astronautas \\ 1758, 12227-010, São José dos Campos, Brazil \\ ${ }^{5}$ Wageningen University \& Research (Alterra), Wageningen, the Netherlands \\ ${ }^{6}$ CAVElab - Computational and Applied Vegetation Ecology, Department of Applied Ecology and Environmental Biology, \\ Faculty of Bioscience Engineering, Ghent University, Coupure Links 653, 9000 Ghent, Belgium \\ ${ }^{7}$ School of Geography, University of Leeds, Leeds, UK \\ ${ }^{8}$ Earth System Analysis, Potsdam Institute for Climate Impact Research (PIK), P.O. Box 6012 03, Telegraphenberg A62, \\ 14412 Potsdam, Germany \\ ${ }^{9}$ School of Geosciences and Environment, Universidad Nacional de Colombia, Medellín, Colombia \\ ${ }^{10}$ TUM School of Life Sciences Weihenstephan, Land Surface-Atmosphere Interactions, Technical University of Munich, \\ Freising, Germany \\ ${ }^{11}$ Centro de Ciência do Sistema Terrestre (CCST), Instituto Nacional de Pesquisas Espaciais (INPE), Rodovia Presidente \\ Dutra km 39, CP 01, CEP: 12630-000, Cachoeira Paulista, São Paulo, Brazil \\ ${ }^{12}$ State Key Laboratory of Hydrology-Water Resources and Hydraulic Engineering, and College of Hydrology and Water \\ Resources, Hohai University, 1 Xikang Road, Nanjing, China
}

Correspondence to: Matthieu Guimberteau (matthieu.guimberteau@1sce.ipsl.fr)

Received: 22 August 2016 - Discussion started: 24 August 2016

Revised: 5 January 2017 - Accepted: 9 February 2017 - Published: 9 March 2017

\begin{abstract}
Deforestation in Amazon is expected to decrease evapotranspiration (ET) and to increase soil moisture and river discharge under prevailing energy-limited conditions. The magnitude and sign of the response of ET to deforestation depend both on the magnitude and regional patterns of land-cover change (LCC), as well as on climate change and $\mathrm{CO}_{2}$ levels. On the one hand, elevated $\mathrm{CO}_{2}$ decreases leaf-scale transpiration, but this effect could be offset by increased foliar area density. Using three regional LCC scenarios specifically established for the Brazilian and Boli-
\end{abstract}

vian Amazon, we investigate the impacts of climate change and deforestation on the surface hydrology of the Amazon Basin for this century, taking 2009 as a reference. For each LCC scenario, three land surface models (LSMs), LPJmLDGVM, INLAND-DGVM and ORCHIDEE, are forced by bias-corrected climate simulated by three general circulation models (GCMs) of the IPCC 4th Assessment Report (AR4). On average, over the Amazon Basin with no deforestation, the GCM results indicate a temperature increase of $3.3^{\circ} \mathrm{C}$ by 2100 which drives up the evaporative demand, whereby 
precipitation increases by $8.5 \%$, with a large uncertainty across GCMs. In the case of no deforestation, we found that ET and runoff increase by 5.0 and $14 \%$, respectively. However, in south-east Amazonia, precipitation decreases by $10 \%$ at the end of the dry season and the three LSMs produce a $6 \%$ decrease of ET, which is less than precipitation, so that runoff decreases by $22 \%$. For instance, the minimum river discharge of the Rio Tapajós is reduced by $31 \%$ in 2100 . To study the additional effect of deforestation, we prescribed to the LSMs three contrasted LCC scenarios, with a forest decline going from 7 to $34 \%$ over this century. All three scenarios partly offset the climate-induced increase of ET, and runoff increases over the entire Amazon. In the southeast, however, deforestation amplifies the decrease of ET at the end of dry season, leading to a large increase of runoff (up to $+27 \%$ in the extreme deforestation case), offsetting the negative effect of climate change, thus balancing the decrease of low flows in the Rio Tapajós. These projections are associated with large uncertainties, which we attribute separately to the differences in LSMs, GCMs and to the uncertain range of deforestation. At the subcatchment scale, the uncertainty range on ET changes is shown to first depend on GCMs, while the uncertainty of runoff projections is predominantly induced by LSM structural differences. By contrast, we found that the uncertainty in both ET and runoff changes attributable to uncertain future deforestation is low.

\section{Introduction}

The Amazon Basin provides a range of ecosystem services. The rivers are used for navigation and hydropower; the forest is an important global sink and store of carbon, and a store of biodiversity; evaporation provides a water vapour source for rainfall downwind. When analysing changes to this ecosystem, it is important to take an integrated approach because each of these services may be affected by, or may affect, the others. Currently, two major changes are taking place simultaneously in Amazonia: deforestation and climate change. From the middle 1970s, southern Amazonia has experienced widespread deforestation (Moran, 1993) with forest being cleared to create new pasture and cropland (Fearnside, 2005). About $7.3 \%$ of the Amazon Basin was deforested between 1976 and 2003 (Callède et al., 2008) and a further $2.6 \%$ between 2000 and 2010 (Song et al., 2015). At the same time, the background level of $\mathrm{CO}_{2}$ has been rising and the climate has been changing in response (IPCC, 2013). These changes are expected to continue, to some degree, for the rest of this century.

Here, we focus on future changes to the river hydrology of the Amazon Basin. For different deforestation scenarios, we model the changes in river flow from grid-based drainage and runoff estimated by different land surface models (LSMs) driven by forcing data derived from general cir- culation model (GCM) output. Because of the long transit times of water moving from soil to the mouth of the Amazon, to simulate discharge requires LSMs to be coupled to a river routing scheme (Biemans et al., 2009; Guimberteau et al., 2012; Langerwisch et al., 2013).

The climate of the Amazon Basin is notoriously difficult to model and there is a wide between-GCM variation in the estimated precipitation and its changes (Boisier et al., 2015). This introduces a first level of uncertainty.

Equally, several LSMs exist and, to a greater or lesser extent, they all incorporate existing process knowledge into their parameterizations (Gash et al., 2004; Keller et al., 2009). However, because of their different structures and the values of the parameters used, LSMs also simulate a range of changes in the water and energy balances even when forced by the same input climate data. The differences between models' results relate in a complex way to simulated vegetation structure, phenology and physiology as well as to soil hydrological processes. This introduces a second level of uncertainty.

A third level of uncertainty stems from the land-cover change (LCC) scenarios used. Observed historical deforestation rates in Amazonia are substantially different from the rates projected in the SSPs (Shared Socioeconomic Pathways) of global scenarios (Representative Concentration Pathways, RCPs) used for the last CMIP (Coupled Model Intercomparison Project) assessment. This disparity questions the realism of the globally projected rates of deforestation when considering the regional scales (Soares-Filho et al., 2006; Kay et al., 2013). For instance, the previous decade witnessed a drastic change in the deforestation dynamics in the Brazilian Amazon (Dalla-Nora et al., 2014). Until the beginning of the last decade, the aggressive deforestation and illegal land appropriation processes in the region (Becker, 1997, 2004; Alves, 2002) seemed to be uncontrollable, peaking at $27772 \mathrm{~km}^{2} \mathrm{yr}^{-1}$ in 2004 (INPE, 2016). Clear-cut deforestation rates have been decreasing since then, oscillating around $6000 \mathrm{~km}^{2} \mathrm{yr}^{-1}$ during the last 5 years. Previous scenario modelling exercises (Laurance et al., 2001; Soares-Filho et al., 2006; Lapola et al., 2011), which have attempted to project deforestation rates for the Brazilian Amazon, highly overestimated the deforestation after 2004. Recent analyses have discussed the role of commodity prices and other economic factors, such as the soy and beef moratoriums, in the slowdown of deforestation rates, although most studies have unveiled the integrated set of actions taken by the Brazilian government to curb deforestation as a decisive factor (Assunção et al., 2012; Macedo et al., 2012; Malingreau et al., 2012; Boucher et al., 2013; Nepstad et al., 2014). These measures included the creation of protected areas, the use of effective monitoring and control systems and credit restriction mechanisms. The SSPs probably also failed to capture the recent trajectory of regional LCC because they do not integrate regional land management policies, existing or future road building or the establishment of conservation ar- 

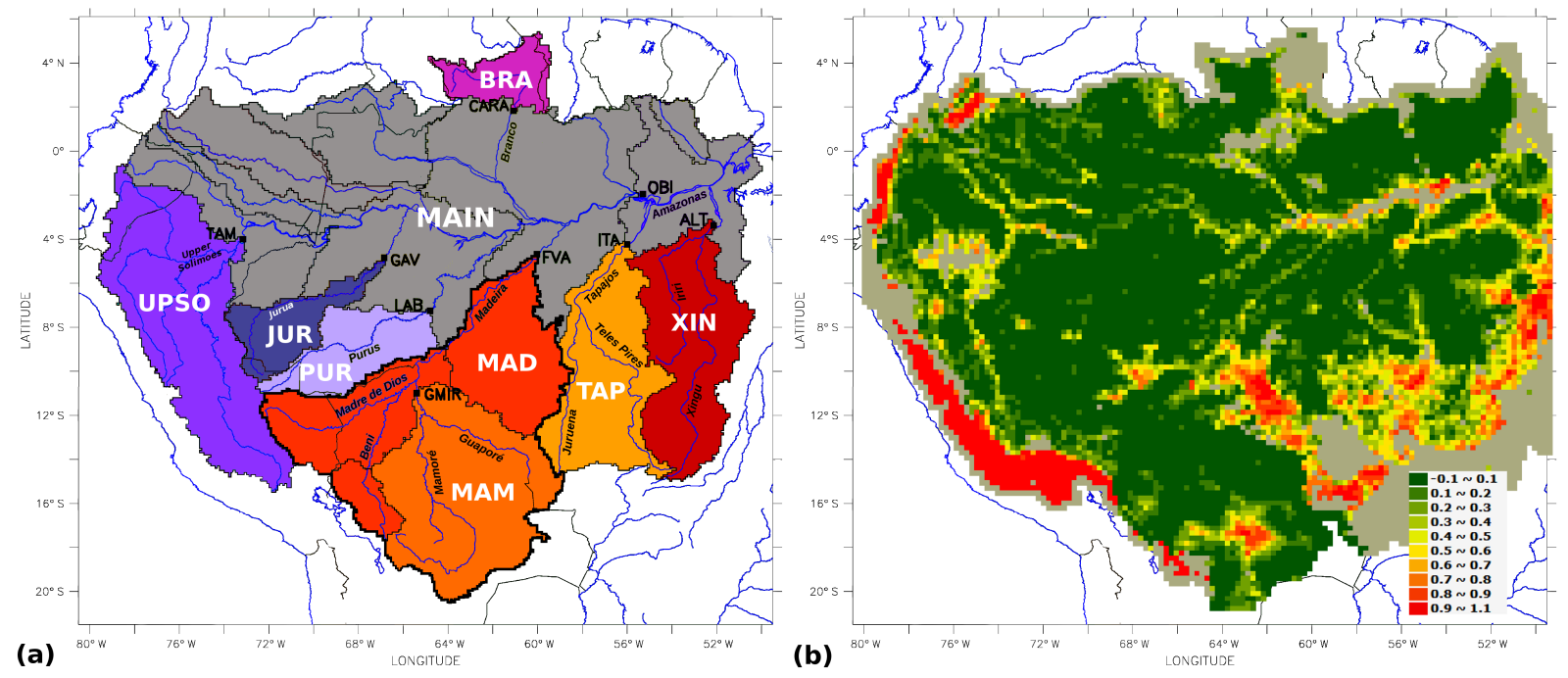

Figure 1. Panel (a) indicates Amazon catchments (names in white; the abbreviations are indicated in Table S1) and the main rivers (adapted from Guimberteau et al., 2012), with localization of the main SO HYBAM gauging stations (the abbreviations are indicated in Table S1). The bold black line delineates the Madeira catchment. Colour is used to distinguish the southern (red), western (purple) and northern catchments (pink). Panel (b) indicates the percentage of deforestation in each $25 \times 25 \mathrm{~km}^{2}$ in 2005 (observed data; Aguiar et al., 2016).

eas (Dalla-Nora et al., 2014). At the same time, the future of the region remains highly uncertain, as several factors may contribute to the return of high deforestation rates, including the rapidly expanding global markets for agricultural commodities, large-scale transportation and energy infrastructure projects and weak institutions (Aguiar et al., 2016). In this complex context, in order to better represent the current situation of the region, we adopted the updated and contrasting scenarios generated in the scope of the AMAZALERT project (raising the alert about critical feedbacks between climate and long-term land use change in the Amazon, http://www.eu-amazalert.org/home) for this study.

Here, we apply for the first time three grid-based LSMs forced by three different GCM climate projections and more realistic regional LCC scenarios, combining the effect of uncertainty in GCM forcing data, LSM structure and LCC future scenarios, and allowing us to estimate the magnitude of likely future hydrological changes due to deforestation and climate change and their uncertainty. In particular, we discuss the relative contribution of GCM uncertainty, LSM uncertainty and LCC scenario uncertainties in future projections of runoff and evapotranspiration (ET) fluxes, with a special focus on the more vulnerable southern Amazon catchments.

\section{Materials and methods}

\subsection{Simulation design and models}

The time frame studied includes a present period representing current climate conditions (1970-2008) and 21st cen- tury projections (2009-2100). Although the domain used in the simulations described below includes the whole Amazon Basin (Fig. 1a and Table S1 in the Supplement), the analysis focuses on the catchments sensitive to deforestation (Fig. 1b). We selected the southern catchments, which are subjected to a distinct dry season today, and are both sensitive to future precipitation changes (Guimberteau et al., 2013; Boisier et al., 2015) and vulnerable to future deforestation (Coe et al., 2009; Costa and Pires, 2010). These catchments are the Rio Madeira (MAD) and its upstream tributary, the Mamore (MAM), and the two large south-eastern catchments of the Tapajós (TAP) and Xingu (XIN) (Fig. 1a). We also chose three western catchments, the Purus (PUR), Juruá (JUR) and upper Solimões (UPSO), and the northern Rio Branco catchment (BRA). These catchments have also experienced deforestation (Nóbrega, 2012; Lima et al., 2014; Barni et al., 2015). The river discharge of the Amazon Basin is taken from the gauging station at Óbidos. Although this station is the closest to the mouth of the Amazon, it is upstream from the confluence of the Tapajós and Xingu with the main stem of the Amazon (Fig. 1a). The Óbidos data therefore do not contain the contribution of these rivers.

We used three LSMs, namely LPJmL-DGVM, which simulates daily water budgets interactively with changes in vegetation physiology, and ORCHIDEE and INLAND-DGVM, which operate with a $30 \mathrm{~min}$ time step (see Table 1 and description in supplementary material). These three models represent the state-of-the-art LSMs inclusive of ecosystem processes controlling runoff and river routing schemes. ORCHIDEE and LPJmL-DGVM are traditionally used for the ISIMIP project (Inter-Sectoral Impact Model Intercomparison Project; https://www.isimip.org/). INLAND-DGVM has 
Table 1. Models used in this study.

\begin{tabular}{|c|c|c|c|c|}
\hline Model & Institute & Reference & Model setup & Resolution \\
\hline ORCHIDEE $^{1}$ & IPSL, Paris, France & Krinner et al. (2005) & River routing & $1.0^{\circ}$, half-hourly \\
\hline INLAND-DGVM $^{2}$ & NPE, São José dos Campos, Brazil & $\begin{array}{l}\text { Foley et al. (1996) } \\
\text { Kucharik et al. (2000) }\end{array}$ & No river routing & $1.0^{\circ}$, half-hourly \\
\hline LPJmL-DGVM ${ }^{3}$ & PIK, Potsdam, Germany & Sitch et al. (2003) & River routing & $1.0^{\circ}$, daily \\
\hline
\end{tabular}

${ }^{1}$ ORganising Carbon and Hydrology In Dynamic EcosystEms. ${ }^{2}$ INtegrated model of LAND surface processes. ${ }^{3}$ Lund Potsdam Jena managed Land model.

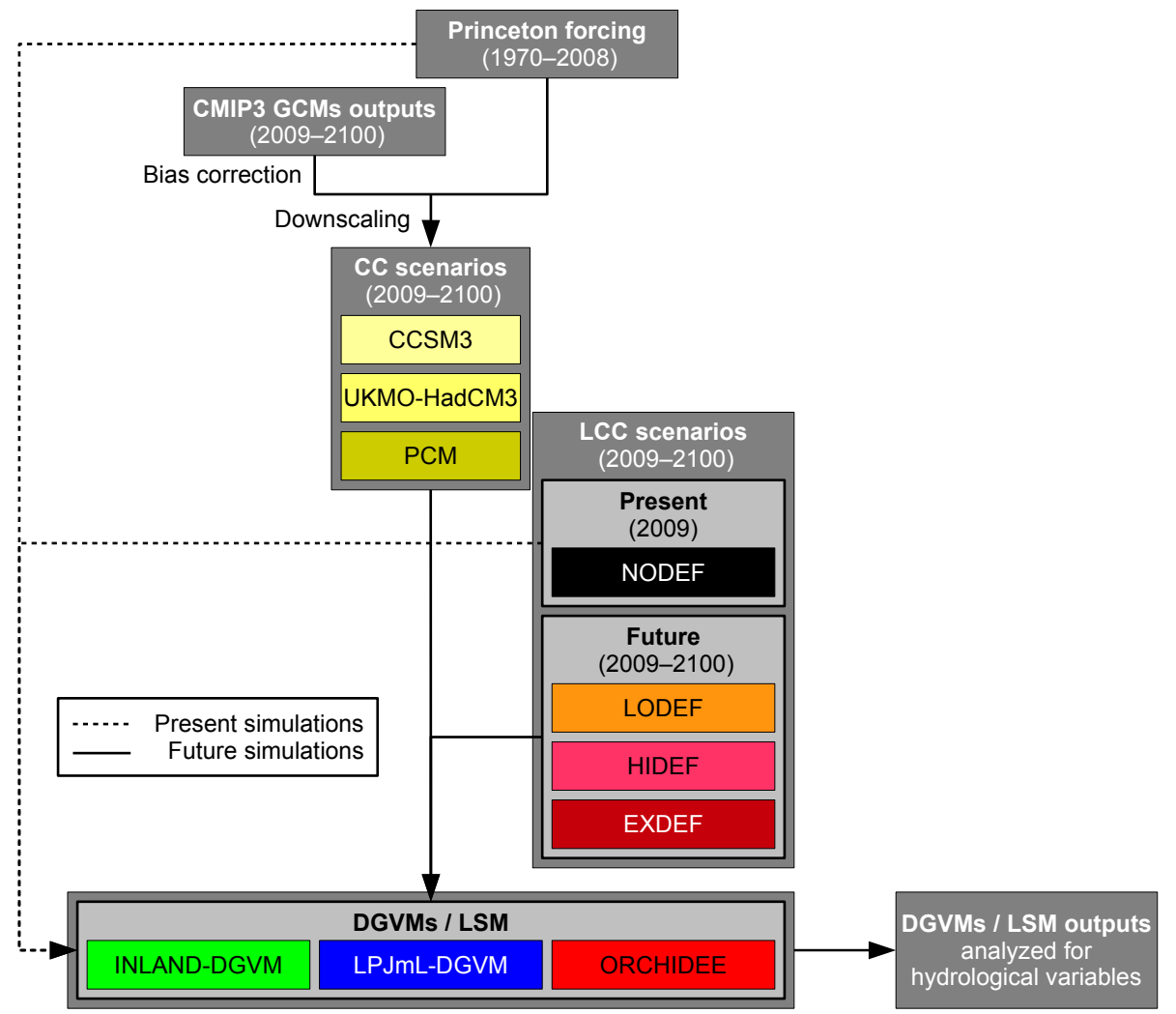

Figure 2. Flow chart methodological approach for present and future simulation processes (CC indicates climate change, LCC indicates land-cover change). Abbreviations of the LCC scenarios are explained in Table 4.

been widely tested over South American biomes to represent the biosphere-atmosphere interactions. Thus, the three LSMs are representative of the diversity of approaches to describe the functioning of the coupled system vegetation hydrology. Moreover, two out of three models integrate different river routing schemes and are thus able to simulate the change of river discharge with climate change and in interaction with the LCC.

First, we performed an historical simulation (1850-2008) where we forced the LSMs with pre-industrial land cover and the Princeton global climate (Sheffield et al., 2006) at a $1^{\circ} \times 1^{\circ}$ spatial resolution and 3-hourly temporal resolution (Fig. 2). This forcing is based on the National Center for Environmental Prediction - National Center for Atmospheric Research (NCEP-NCAR) 6-hourly reanalysis data sets (Kistler et al., 2001) with precipitation, air temperature and radiation biases corrected by hybridization with global monthly gridded observations. The corrected precipitation was disaggregated in space by a statistical downscaling at $1^{\circ}$ resolution using relationships developed by the Global Precipitation Climatology Project (GPCP; Huffman et al., 2001) and in time from daily to 3-hourly using the Tropical Rainfall Measuring Mission (TRMM; Huffman et al., 2007) satellite data. A 300-year spin-up was performed by each LSM to ensure equilibrium of carbon and water pools by recycling the Princeton forcing over the period 1970-2008 with constant pre-industrial atmospheric $\mathrm{CO}_{2}$ concentration representative of the year 1850 (278 ppm). Starting from the end of the spinup state, all the LSMs did the simulation HIST over 18502008, forced with increasing $\mathrm{CO}_{2}$ (from 278 to $385 \mathrm{ppm}$ ) and 
also by recycling the Princeton forcing. We only kept the 39year period from 1970 to 2008 as the reference simulation of present conditions (HIST simulation; Table 2). Neither the spin-up nor the HIST runs account for LCC. Each LSM used its own definition of natural land cover and soil parameters. The LSMs were not calibrated at the present time. Their performance to simulate ET and river discharge in the HIST simulation is summarized in Table S2. Other evaluations over the Amazon Basin for the present time can be found in Langerwisch et al. (2013) for LPJmL-DGVM, in Dias et al. (2015) and Lyra et al. (2016) for INLAND-DGVM and in Guimberteau et al. $(2012,2014)$ for ORCHIDEE.

Using HIST as initial conditions, multiple future simulations with each LSM forced by three GCMs (see Sect. 2.2) were run from 2009 to 2100 (Table 2, Fig. 2) with increasing $\mathrm{CO}_{2}$ from the Special Report on Emissions Scenarios (SRES) A2 scenario (388 to $856 \mathrm{ppm}$ ). First, to define the hydrological response to climate change only, we performed a future simulation with land cover set constant at the value for the year 2009 for each LSM (NODEF; Table 2). Then, in order to separate the impacts of future deforestation, we prescribed to each LSM three annual LCC spatial projections (Fig. 2), generated in the scope of the AMAZALERT project, described in Sect. 2.3.

\subsection{Climate change scenarios}

The projections of future climate (2009-2100) were obtained from simulations of three GCMs from CMIP3 under the SRES A2 scenario for which sub-daily outputs were available for driving LSMs, including the Parallel Climate Model (PCM), the Community Climate System Model (CCSM3) and the Hadley Centre Coupled Model (UKMO-HadCM3) (Table 3). The outputs of the three GCMs were regridded to $1.0^{\circ}$ and $1 \mathrm{~h}$ resolution using interpolation approaches and corrected for biases (Zhang et al., 2015; Moghim et al., 2017). Biases in precipitation and temperature fields were corrected by applying the equidistant cumulative distribution function (EDCDF) matching method (Moghim et al., 2017). Specific humidity and downward longwave radiation were then correspondingly adjusted using the bias-corrected temperature data (Moghim et al., 2017). The method for spatial interpolation is the bilinear interpolation. For temporal disaggregation of different models' output variables, two statistical methods were used. CCSM3 generates and stores precipitation data instantaneously every 6h, while UKMO-HadCM3 and PCM produces 6- and 3hourly accumulated precipitation values, respectively. Therefore, two different methods are used for hourly disaggregation of precipitation obtained from these models. Linear temporal interpolation is used for disaggregation of 6-hourly instantaneous CCSM3 precipitation, while a stochastic approach developed for the disaggregation of accumulated precipitation is applied to the UKMO-HadCM3 and PCM precipitation. A method that incorporates the solar zenith angle
Table 2. List of the different simulations performed with the three LSMs (ORCHIDEE, INLAND-DGVM and LPJmL-DGVM) with or without climate change (CC) and land-cover change (LCC).

\begin{tabular}{lll}
\hline \multirow{2}{*}{$\begin{array}{l}\text { Name of the } \\
\text { simulation }\end{array}$} & \multicolumn{2}{c}{ Scenarios } \\
\hline HIST & no & no \\
\hline CCSM3 NODEF & yes & no \\
CCSM3 LODEF & yes & yes \\
CCSM3 HIDEF & yes & yes \\
CCSM3 EXDEF & yes & yes \\
\hline UKMO-HadCM3 NODEF & yes & no \\
UKMO-HadCM3 LODEF & yes & yes \\
UKMO-HadCM3 HIDEF & yes & yes \\
UKMO-HadCM3 EXDEF & yes & yes \\
\hline PCM NODEF & yes & no \\
PCM LODEF & yes & yes \\
PCM HIDEF & yes & yes \\
PCM EXDEF & yes & yes \\
\hline
\end{tabular}

is used to disaggregate shortwave radiation, while the other meteorological variables are interpolated linearly. Additional details of the downscaling and bias-correction methods are described in Moghim et al. (2017).

\subsection{Deforestation scenarios}

The Amazon Basin is located in the countries of Bolivia, Brazil, Colombia, Ecuador, Peru and Venezuela. Each country in the basin has its own socioeconomic and institutional context-specific aspects to be taken into consideration when building scenarios in order to avoid oversimplifications. Our methodological choice was to generate new updated scenarios only for Brazil and Bolivia, the most important deforestation hotspots in the basin. The Brazilian portion of the basin covers approximately $50 \%$ of the area, being also where most of the deforestation hotspots have been located in the previous decades. Bolivia has also been facing an intensive deforestation process for agricultural expansion around the Santa Cruz area. For the other countries, existing spatial projections were used.

The scenario process followed the "story and simulation" (SAS) approach largely adopted in environmental scenarios (Raskin, 2005; Alcamo, 2008). Two stakeholder workshops were held for discussing the whole Brazilian Amazon future, along four axes: natural resources, social development, economic activities and institutional context. The results are multidimensional and rich qualitative storylines. Scenario A is a "sustainability" scenario in terms of socioeconomic, institutional and environmental dimensions, with no deforestation and massive forest restoration. Scenario B stays in the "middle of the road", maintaining some of the positive trends of the last decade (in the case of Brazil), but 
Table 3. List of the GCMs participating in CMIP3 used in this study with their approximate atmospheric horizontal resolution.

\begin{tabular}{|c|c|c|c|c|}
\hline \multirow[t]{2}{*}{ Institutes, country } & \multicolumn{2}{|l|}{ Model } & \multirow{2}{*}{$\begin{array}{l}\text { Resolution } \\
(\text { lat } \times \text { long) }\end{array}$} & \multirow[t]{2}{*}{ References } \\
\hline & Name & Abbreviations & & \\
\hline National Center for Atmospheric Research (NCAR), USA & $\begin{array}{l}\text { Community Climate System Model } \\
\text { Parallel Climate Model }\end{array}$ & $\begin{array}{l}\text { CCSM3 } \\
\text { PCM }\end{array}$ & $\begin{array}{l}1.4^{\circ} \times 1.4^{\circ} \\
\sim 2.8^{\circ} \times 2.8^{\circ}\end{array}$ & $\begin{array}{l}\text { Bonan et al. (2002) } \\
\text { Washington et al. (2000) }\end{array}$ \\
\hline $\begin{array}{l}\text { Hadley Centre for Climate Prediction } \\
\text { and Research/Met Office, UK }\end{array}$ & Hadley Centre Coupled Model & UKMO-HadCM3 & $\sim 2.5^{\circ} \times 3.75^{\circ}$ & Gordon et al. (2000) \\
\hline
\end{tabular}

not reaching the full potential from an integrated socioeconomic, institutional and environmental perspective. Finally, Scenario C is a pessimistic scenario, named "fragmentation", consisting of a weakening of the conservation efforts of recent years, including the depletion of natural resources and the return of high deforestation rates.

To feed the spatial model, only some selected elements of the storylines were used - mainly concerning the natural resources theme: (a) deforestation rates; (b) secondary vegetation dynamics; (c) roads and protected areas network; and (d) law enforcement. The quantification process for the Brazilian Amazon is described in Aguiar et al. (2016). For the Bolivian Amazon, expert-driven premises about these same selected elements were adopted - respecting however the Bolivian socioeconomic and political specificities, as explained in Tejada et al. (2015).

Based on these elements, future maps of forest area were then simulated using the LuccME (Land use and cover change Modeling Environment; http://www.terrame. org/luccme) model framework, generating annual forest cover maps until 2100 on a grid of $25 \mathrm{~km}^{2}$ for the Brazilian Amazon (Aguiar et al., 2016) and the Bolivian Amazon (Tejada et al., 2015).

LuccME (Aguiar et al., 2012) is a generic framework to build land-use demand-potential-allocation models. Land change decisions are controlled by an allocation mechanism which uses the suitability of each cell for a given land change transition (potential of change) to distribute a given amount (demand) of change in space. LuccME allows the construction of LUCC models combining existing demand, potential and allocation components according to the needs of a given application and scale of analysis. The modelling components adopted to build the LuccME/BRAmazon and LuccME/Bolivia models are based on the ideas of the Clue model (Verburg et al., 2002). In the allocation model, cells with positive change potential will receive a percentage of the annual deforestation rate expected to be allocated to the whole area. The amount of change (i.e. new deforestation) in each cell will be proportional to the cell potential, which is recomputed, every year, considering not only the temporal changes in the spatial drivers but also the distance to previously opened areas.

For the Brazilian Amazon, annual spatially explicit deforestation maps from 2002 to 2013, provided by the PRODES (Program for the Estimation of Deforestation in the Brazil- ian Amazon) system (INPE, 2016), were used to calibrate and validate the parameters of the deforestation model, as detailed in Aguiar et al. (2016) (LuccME/BRAmazon). The main drivers are related to accessibility (connection to national markets and distance to markets), protected areas and soil fertility. Using these variables, the model correctly captured the different stages of occupation of the new Amazonia frontiers from 2002 to 2013 (Aguiar et al., 2016). The scenario projections generated for the AMAZALERT project cover the period 2014 to 2100 . The same premises described by Aguiar et al. (2016) were used to extend the projections from 2050 to 2100 . The modelling process for the Bolivian Amazon (LuccME/Bolivia) was similar. The main spatial drivers considered in the model are connectivity to markets, distance to roads, protected areas and slope (Tejada et al., 2015). The observed deforestation data were drawn from the NKMMNH (Noel Kempff Mercado Museum of Natural History; Killeen et al., 2012) from 2001 to 2008. In this case, the scenario projections run from 2009 to 2100, adapting the premises described by Tejada et al. (2015) from 2050 to 2100.

To generate basin-wide LCC projections, the annual spatially explicit results for Brazil and Bolivia were combined with the existing "business-as-usual" projection (defined by the continuation of the current trend) to the other countries, based on historical deforestation trends, as part of the EUfunded ROBIN (Role Of Biodiversity In climate change mitigatioN) project (Eupen et al., 2014).

In this paper, we explore the effects of Scenario A and Scenario $\mathrm{C}$ contrasting storylines. Scenario A storyline quantification produced low forest loss (LODEF), whilst Scenario C was quantified into a high (HIDEF) and extreme (EXDEF) forest area loss for the Brazilian Amazon (Table 4). Figure S1 in the Supplement illustrates the basin-wide maps, combining the LuccME/BRAmazon, the LuccME/Bolivia and the other countries' spatial projections (Eupen et al., 2014). As Fig. S1 illustrates, the results were combined into a $25 \mathrm{~km}^{2} \times 25 \mathrm{~km}^{2}$ grid cell for the whole basin, containing annual information (from 2005 to 2100) about the percentage of the cell area that was deforested up to that year. These three LCC scenarios (LODEF, HIDEF and EXDEF) were translated into model parameters and prescribed to each LSM (Table 2, Fig. 2) from 2009 to 2100. 
Table 4. LCC scenarios used in this study.

\begin{tabular}{|c|c|c|c|c|c|}
\hline \multicolumn{2}{|c|}{ Qualitative scenarios } & \multicolumn{4}{|c|}{ Quantification of deforestation rates (spatially explicit projections until 2100) } \\
\hline Name & Brief storyline & Name & $\begin{array}{l}\text { Brazilian Amazon } \\
\text { (Aguiar et al., 2016) }\end{array}$ & $\begin{array}{l}\text { Bolivian Amazon } \\
\text { (Tejada et al., 2015) }\end{array}$ & $\begin{array}{l}\text { Other countries } \\
\text { (Eupen et al., 2014) }\end{array}$ \\
\hline A - Sustainability & $\begin{array}{l}\text { "Zero" deforestation scenario: } \\
\text { sustainable land use, } \\
\text { protected areas, } \\
\text { indigenous territories, } \\
\text { restrained construction } \\
\text { of new roads }\end{array}$ & LODEF & $\begin{array}{l}\text { Annual rate decreasing } \\
\text { to } 3900 \mathrm{~km}^{2} \mathrm{yr}^{-1} \\
\text { until } 2020, \text { and then } \\
\text { to } 1000 \mathrm{~km}^{2} \mathrm{yr}^{-1} \\
\text { until } 2025 \text {, and then } \\
\text { stabilizing until } 2100\end{array}$ & $\begin{array}{l}\text { Trend of } 2005-2008 \\
\text { until } 2013 \text {, } \\
\text { then decrease by } 50 \%\end{array}$ & Same as HIDEF \\
\hline \multirow[t]{2}{*}{$\mathrm{C}$ - Fragmentation } & \multirow{2}{*}{$\begin{array}{l}\text { Return of high } \\
\text { deforestation } \\
\text { rates }\end{array}$} & HIDEF & $\begin{array}{l}\text { Annual rate increasing } \\
\text { to } 15000 \mathrm{~km}^{2} \mathrm{yr}^{-1} \\
\text { until } 2020 \\
\text { and stabilizing until } 2100\end{array}$ & $\begin{array}{l}\text { Total deforested area reaches } \\
13 \text { million ha in } 2025 \text { ha, } \\
\text { then replicates the } 2005-2008 \\
\text { annual rate }\end{array}$ & $\begin{array}{l}\text { For each country, } \\
\text { projected } \\
\text { according to } \\
\text { historical trends }\end{array}$ \\
\hline & & EXDEF & $\begin{array}{l}\text { Annual rate increasing } \\
\text { to } 19500 \mathrm{~km}^{2} \mathrm{yr}^{-1} \\
\text { (1996-2005 historical rate) } \\
\text { until } 2020 \text { and stabilizing until } 2100\end{array}$ & Same as HIDEF & Same as HIDEF \\
\hline
\end{tabular}

\subsection{Model results analysis}

We selected two 20-year periods, 2040-2059 and 20802099, for LSM output analysis. The impact of future climate change alone was estimated for each LSM by the difference between the results of NODEF and HIST in precipitation, ET, runoff and river discharge (Table 2). The impact of future LCC was estimated by taking the difference, for each LSM and GCM forcing, between the results of future simulations with LCC (LODEF, HIDEF and EXDEF) and without LCC (NODEF). Relative differences are calculated with the same benchmark (HIST simulation).

The spread in the ensemble mean variation (LSMs and GCM forcings) was measured by the interquartile range (IQR). The consistency of the variations in precipitation, ET and runoff were estimated by the signs of the first $\left(Q_{1}\right)$ and the last $\left(Q_{3}\right)$ quartiles. A decrease (increase) was considered to be consistent if $Q_{3}<0\left(Q_{1}>0\right)$.

We quantify the relative contribution of GCMs, LSMs and LCC scenarios to uncertainty using an analysis of variance (ANOVA) framework as in, e.g. Yip et al. (2011), Sansom et al. (2013) and Giuntoli et al. (2015). ANOVA partitions a total sum of squares into portions associated with the various factors. The effect size statistic is usually called $\eta^{2}$ which quantifies the proportion of total variance attributed to each factor.

\section{Results}

\subsection{Future scenarios}

\subsubsection{Climate}

By the end of the 21st century, GCM-mean annual temperature increases by $3.3^{\circ} \mathrm{C}$ in Amazonia. The forcing from the
GCM chosen in this study spans the range of climate predictions for Amazonia (Malhi et al., 2009; Zhang et al., 2015). The UKMO-HadCM3 GCM is the driest and warmest model $\left(+4.5^{\circ} \mathrm{C}\right)$, predicting Amazon rainfall reductions twice as large as any other CMIP3 GCM (Covey et al., 2003; Cox et al., 2004); PCM simulates a slightly warmer $\left(+1.7^{\circ} \mathrm{C}\right)$ but wetter future climate compared to the current climate; and CCSM3 falls in between $\left(+3.6^{\circ} \mathrm{C}\right)$ (Zhang et al., 2015). The strongest warming of $6.1^{\circ} \mathrm{C}$ by 2100 is found in eastern Amazonia with the UKMO-HadCM3 GCM (not shown). Because of the differences in precipitation changes projected by the three GCMs (between -4.5 and $+16.2 \%$ ) by the end of the century, the average increase of precipitation by $8.5 \%$ $\left(190 \mathrm{~mm} \mathrm{yr}^{-1}\right)$ across the three GCMs should be considered as very uncertain (Fig. 3a). Precipitation changes are also spatially contrasted. Western and northern Amazonia tend to become wetter in all GCM models, with annual precipitation increases going from 6.5 to $11 \%$ (Figs. 3a and $4 \mathrm{a}$ ). In the upper Solimões and the Branco catchments, the three GCM forcings give an increase of precipitation. Southern Amazonia also becomes wetter, in particular the Madeira catchment where the three GCM forcings give a $5 \%$ increase in precipitation (Fig. 3a) but with spatial differences. In the Madre de Dios region (see Fig. 1a for location), at least two out of the three GCM forcings give a decrease in precipitation (Fig. 4a). In south-eastern Amazonia, there is no change in GCM-mean precipitation over the Tapajós and Xingu catchments but GCM forcings disagree on the sign and magnitude of the change (Fig. 3a). At least two out of the three GCM forcings give a decrease of precipitation in the western part of the Tapajós catchment (Fig. 4a).

We focus on the period corresponding to the end of the dry season, from August to October (ASO). Lower precipitation during this period could have critical effects on the vegetation and hydrology (Malhi et al., 2008). In ASO, the 
(a) Annual mean $\Delta P\left(\mathrm{~mm} \mathrm{yr}^{-1}\right)$

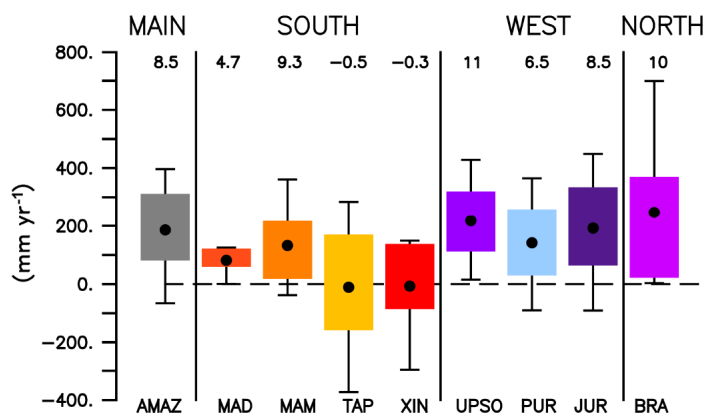

(c) Annual mean $\triangle \mathrm{ET}\left(\mathrm{mm} \mathrm{yr}^{-1}\right)$ (b) ASO mean $\triangle P\left(m m m^{-1}\right)$

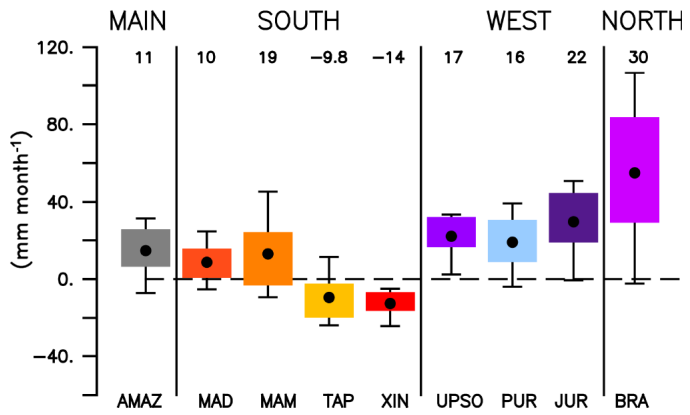

(d) ASO mean $\triangle \mathrm{ET}\left(\mathrm{mm}\right.$ month $\left.^{-1}\right)$

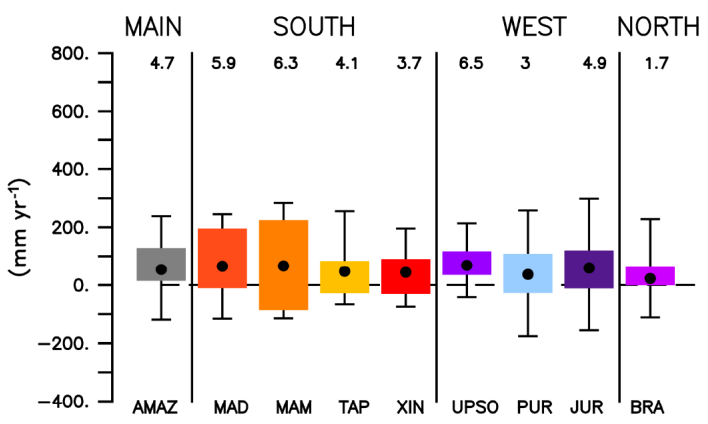

(e) Annual mean $\Delta R\left(m m r^{-1}\right)$

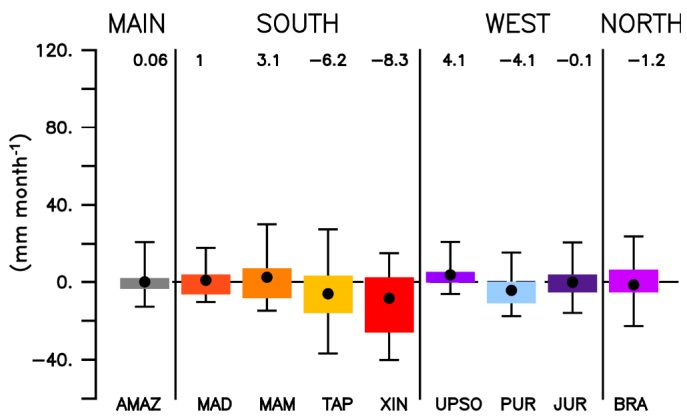

(f) ASO mean $\triangle \mathrm{R}\left(\mathrm{mm}\right.$ month $\left.^{-1}\right)$
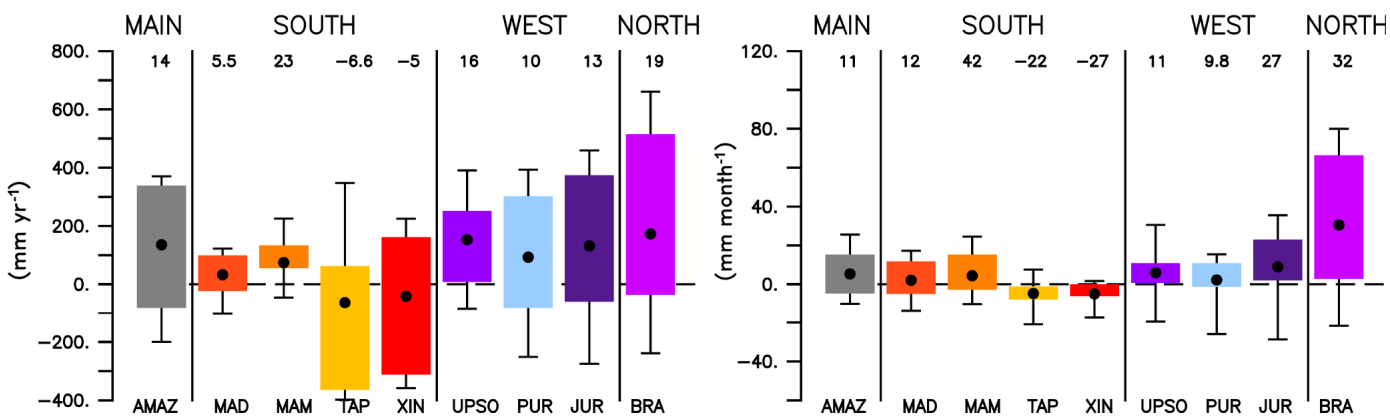

Figure 3. Changes in mean annual $\left(\mathrm{mm} \mathrm{yr}^{-1}\right)$ and August to October (ASO) values $\left(\mathrm{mm} \mathrm{month}^{-1}\right)$ of (a, b) precipitation, (c, d) ET and (e, f) runoff due to climate change only, for the end of the century, over the Amazon Basin and eight of its catchments (the abbreviations of the catchments are indicated in Table S1). Each box plot corresponds to the interquartile range (IQR, distance between the 25th and the 75th percentiles) within each catchment, indicating the spread of the three GCM forcings (for $\Delta P$ ) and three GCM forcings $\times$ three LSMs (for $\Delta \mathrm{ET}$ and $\Delta R$ ) results (see Fig. 1 for colour code). For a given box plot, the black points denote the mean value over the catchment, the whiskers extend from the minimum value to the maximum one and the numbers above the box plot indicate the mean relative differences over the catchment $(\%)$.

spatial patterns of precipitation changes are similar to annual mean changes, but with a larger area of decreased precipitation (Fig. 4a and b). As noticed by Guimberteau et al. (2013), south-eastern Amazonia becomes drier in the middle and at the end of the century, with an average ASO precipitation decrease ranging from 10 to $14 \%$ in the Tapajós and Xingu catchments (Fig. 3b). At least two out of the three GCM forcings give a consistent ASO precipitation decrease in most of the grid cells of these two catchments, particularly in the
Xingu (Fig. 4b). In other southern regions, GCM forcings predict wetter ASO conditions with a larger precipitation increase simulated by UKMO-HadCM3 in the southernmost part of the Madeira catchment compared with the two other GCM forcings (Fig. 4b). In the western and northern catchments, all the GCM forcings predict a consistent precipitation increase during ASO of between 16 and $30 \%$ (Fig. 3b), except in the northernmost part of the upper Solimões catchment (Fig. 4b). 

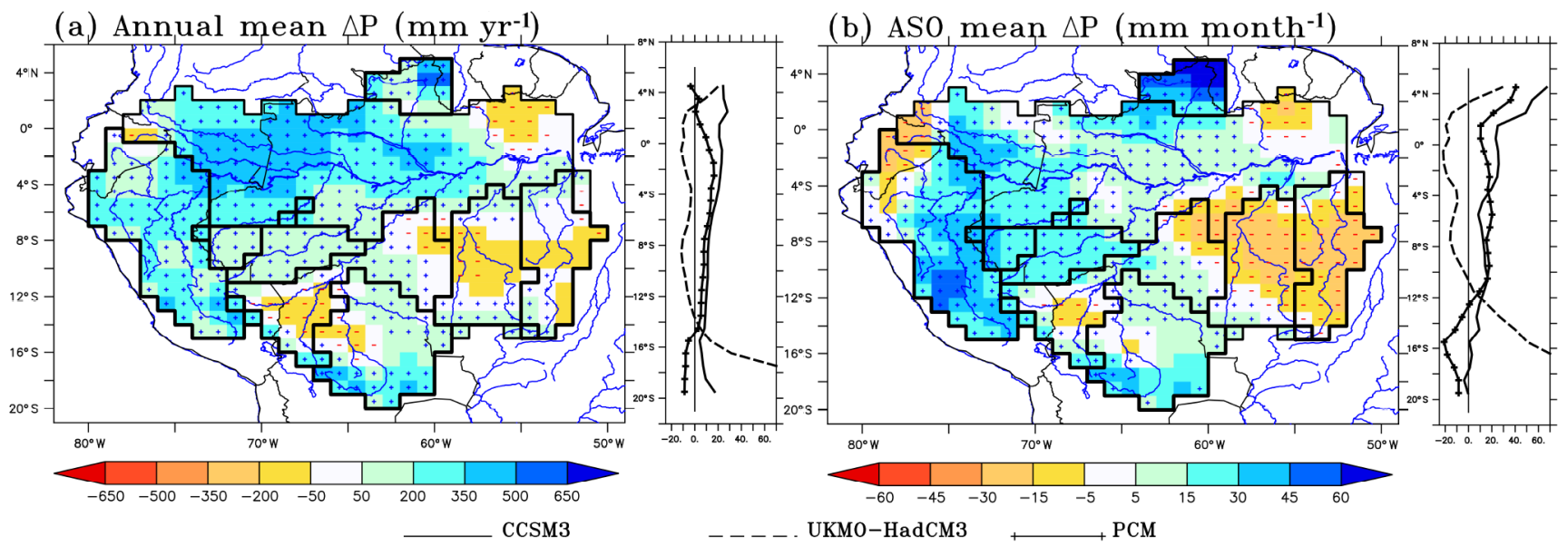

Figure 4. Maps indicate spatial change in (a) annual $\left(\mathrm{mm} \mathrm{yr}^{-1}\right)$ and (b) ASO $\left(\mathrm{mm} \mathrm{month}^{-1}\right)$ precipitation due to climate change (mean of the three GCM forcings) for the end of the century. The symbols indicate that more than two GCM forcings out of three give a precipitation increase (+) or decrease (-) on the grid cell. The black lines delineate the Amazon Basin and the catchments. Plots indicate the corresponding zonal mean of relative changes in precipitation $(\%)$ from the three GCM forcings.

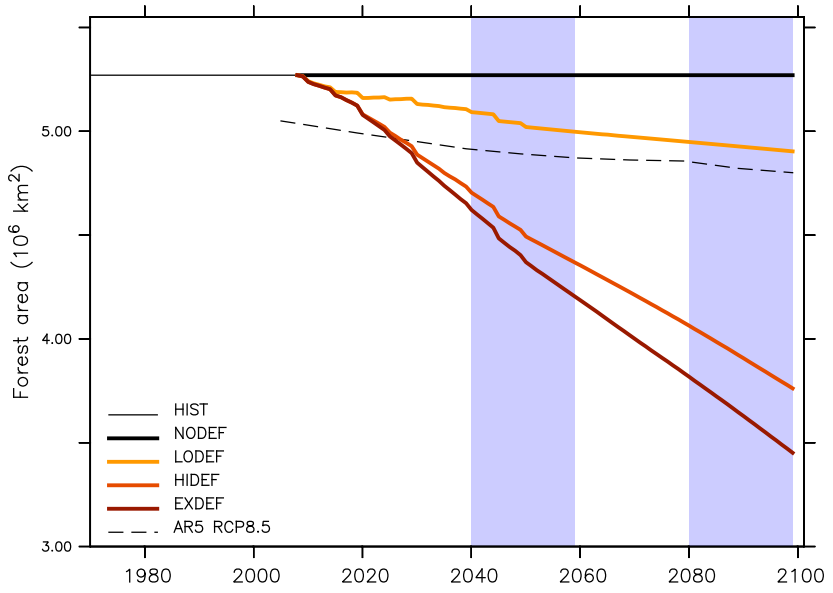

Figure 5. Interannual variation of forest area $\left(10^{6} \mathrm{~km}^{2}\right)$ over the Amazon Basin, according to the NODEF scenario, the three LCC scenarios and the SSP of the AR5 RCP8.5 scenario over 20092099. The blue bands indicate the two future periods selected for this study.

\subsubsection{Land-cover change}

The total area of Amazonian forest prescribed in 2009 is 5.27 million $\mathrm{km}^{2}$, i.e. $89 \%$ of the total area of the whole basin (Fig. 5). The LODEF scenario projects a $7 \%$ decrease in forest area over the Amazon Basin by 2099 relative to 2009 (Fig. 6). By comparison, the SSP land-use scenario with the RCP8.5 emission scenario, which broadly corresponds to the SRES A2 storyline of the GCM climate forcing used in this study, gives a forest area loss of $4.6 \%$ (Fig. 5), relative to a forest area of 5.03 million $\mathrm{km}^{2}$ in 2009 . By contrast, in both HIDEF and EXDEF scenarios, forest area strongly declines during the next century. By 2100, according to the EXDEF

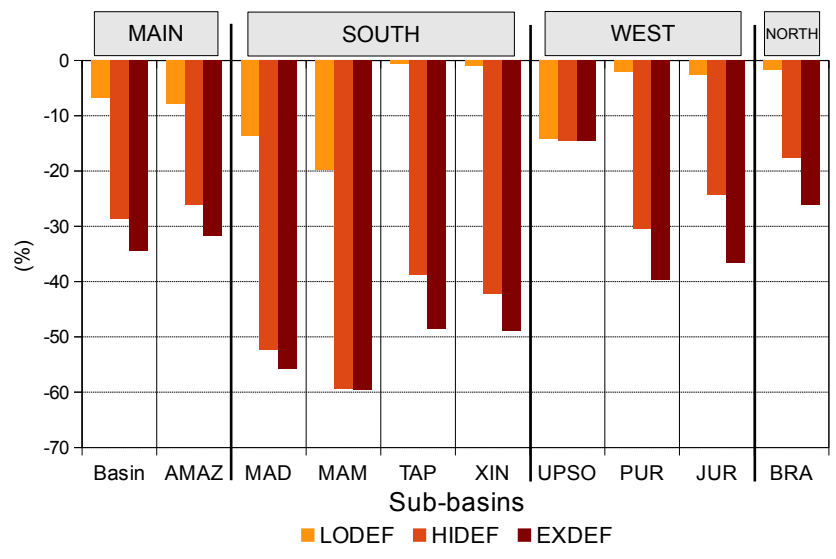

Figure 6. Forest area decrease (\%) over the different catchments of the Amazon Basin between each of the three LCC scenarios in 2099 and the NODEF scenario in 2009 (the abbreviations of the catchments are indicated in Table $\mathrm{S} 1$ ).

scenario, the area of Amazonian forest is reduced to a value of 3.45 million $\mathrm{km}^{2}$ (34\%) (Figs. 5 and 6), i.e. about half of the Amazon Basin. LCC scenarios show a high heterogeneity at the resolution of $0.25^{\circ}$, reflecting how fragmentation is simulated in the LuccME model (Fig. S2). The southern catchments experience the highest deforestation rates during the 21 st century in all scenarios. The Madeira catchment loses some $14 \%$ of its forest area by 2100 in LODEF and more than $50 \%$ in HIDEF and EXDEF (Fig. 6). In the Mamoré southern subcatchment of the Madeira, forest area loss reaches $60 \%$ in HIDEF and EXDEF with the deforested area reaching $100 \%$ in the upstream part of MAM (Fig. S2f). In the southern Tapajós and Xingu catchments, LODEF and EXDEF give contrasting estimates of forest area: in LODEF, forest area changes by only $1 \%$ in 2099 , whereas in EXDEF 


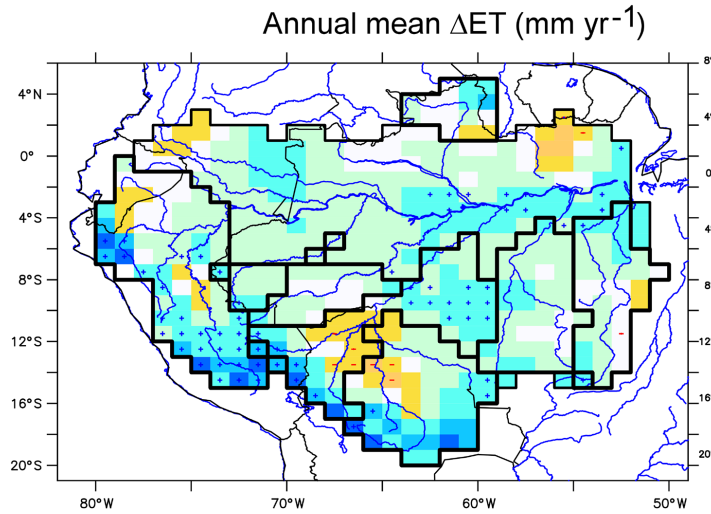

(a)
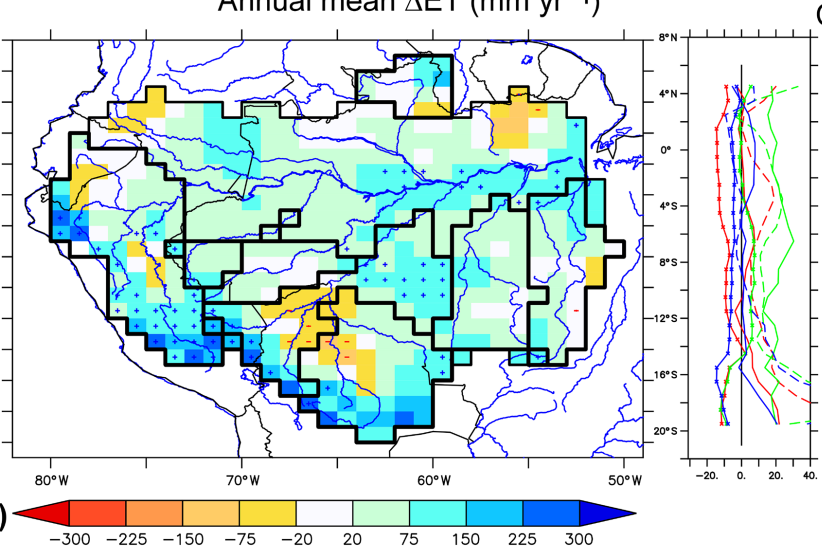

CC

ASO mean $\triangle \mathrm{ET}\left(\mathrm{mm}\right.$ month $\left.^{-1}\right)$

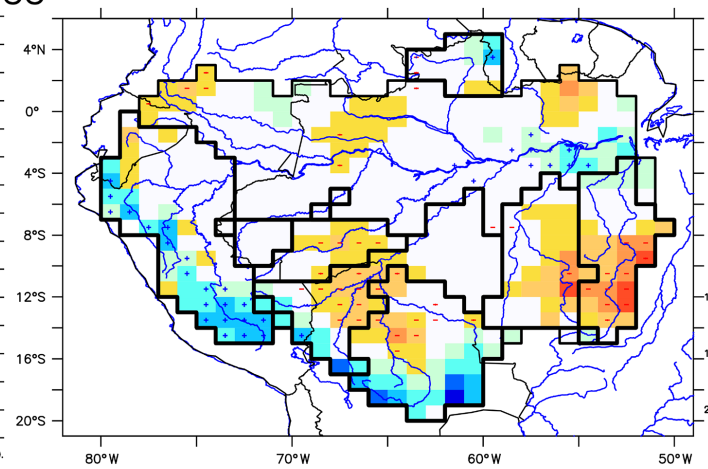

(b)

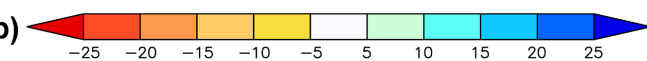

$\mathrm{CC}+\mathrm{LCC}$
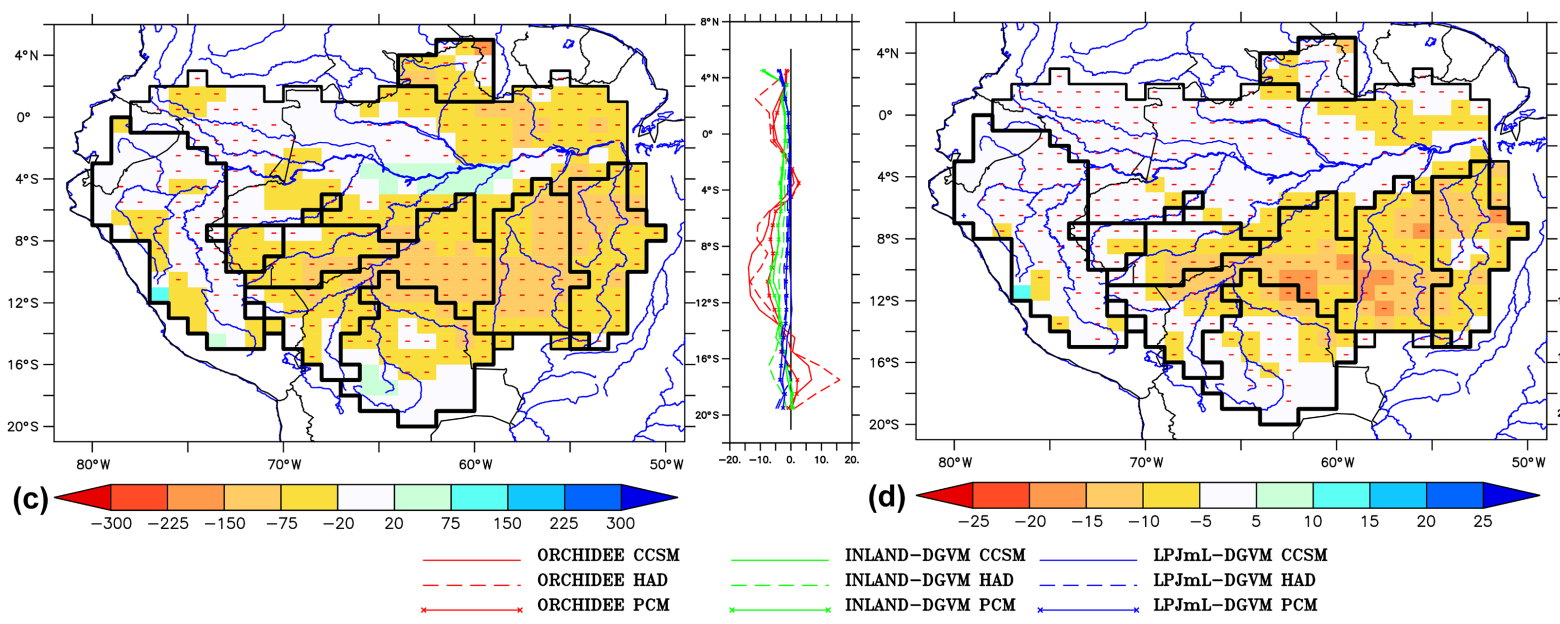

INLAND-DGVM CCSM — LPJML-DGVM CCSM

INUAND-DGTM PCM

Figure 7. Maps indicate spatial change in (a, c) annual $\left(\mathrm{mm} \mathrm{yr}^{-1}\right)$ and $(\mathbf{b}, \mathbf{d})$ ASO $\left(\mathrm{mm} \mathrm{month}^{-1}\right)$ ET due to (a, b) climate change (mean of the three GCM forcings) and (c, d) deforestation combined with climate change (EXDEF) for the end of the century. The symbols indicate that more than six simulations out of nine (three GCM forcings $\times$ three LSMs) give an increase $(+)$ or a decrease $(-)$ of ET on the grid cell. The black lines delineate the Amazon Basin and the catchments. Plots indicate the corresponding zonal mean of relative changes in ET (\%) from each of the nine simulations.

it decreases by approximately $50 \%$ (Fig. 6). The western and northern catchments are projected to lose between 2 and $40 \%$ of their forest area, depending on the LCC scenario.

\subsection{Effects of climate change on ET and runoff}

\subsubsection{Annual mean changes in ET and runoff}

The $8.5 \%$ average increase of GCM-estimated annual precipitation $\left(190 \mathrm{~mm} \mathrm{yr}^{-1}\right)$ by the end of the century results in a $5 \%$ increase in ET $\left(54 \mathrm{~mm} \mathrm{yr}^{-1}\right)$ and a $14 \%$ increase in runoff (136 mm yr${ }^{-1}$ ) over the entire Amazon Basin (Fig. 3a, $\mathrm{c}$ and e, respectively). The ensemble spread in annual ET variation is lower (IQR $=110 \mathrm{~mm} \mathrm{yr}^{-1}$; Fig. 3c) than the change in runoff (IQR $=420 \mathrm{~mm} \mathrm{yr}^{-1}$; Fig. 3e), which is very uncertain. Western parts of the basin become wetter, and ensemble-mean ET and runoff consistently increase by up to 6.5 and $16 \%$, respectively, with a higher spread for runoff variation (IQR $>250 \mathrm{~mm} \mathrm{yr}^{-1}$ ). The largest increase of ensemble-mean runoff (19\%) in the Amazon Basin occurs in the northern catchment where the increase in ET is the smallest $(<2 \%)$. This increase is associated with a large spread between the multiple simulations (IQR close to $600 \mathrm{~mm} \mathrm{yr}^{-1}$ ). In southern parts of the basin, the $5 \%$ increase of the ensemble-mean ET is uncertain when considering the Mamoré and the south-eastern catchments (Fig. 3c). Yet, in the foothills of the Andes, the northern Madeira catchment and along the Amazon River (Fig. 7a), the increase of ET is consistent across the multiple simulations. In the north-western part of the Madeira catchment (Mamoré, Beni and Madre de Dios rivers), with an annual precipitation decrease (Fig. 4a), six out of nine simulations show decrease in ET (Fig. 7a). In the Mamoré subcatchment, mean-ensemble runoff consistently increases by $23 \%$, whereas it decreases by $6 \%$ in the south-eastern catchments. The runoff changes 
(a) Annual mean $\triangle E T(m m ~ y r-1)$

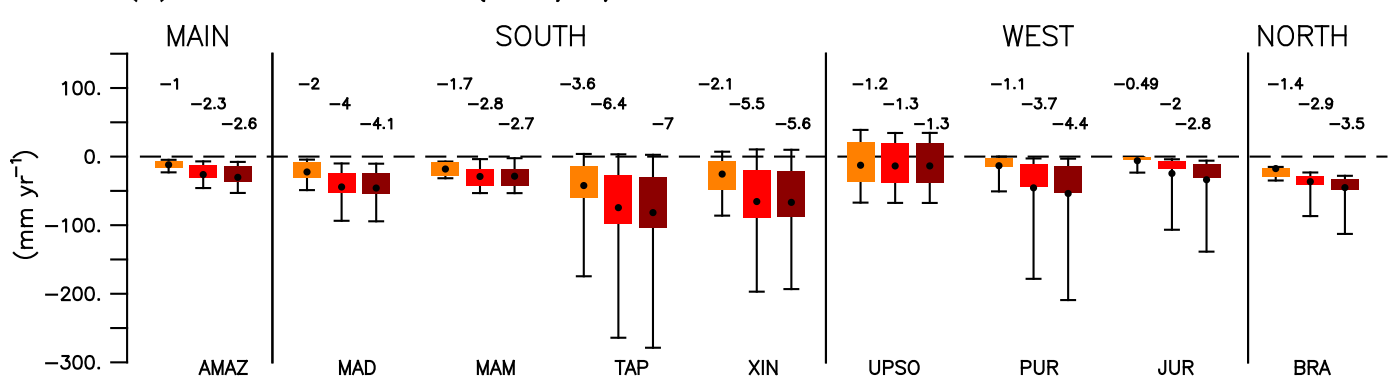

(b) ASO mean $\triangle \mathrm{ET}\left(\mathrm{mm}\right.$ month $\left.^{-1}\right)$

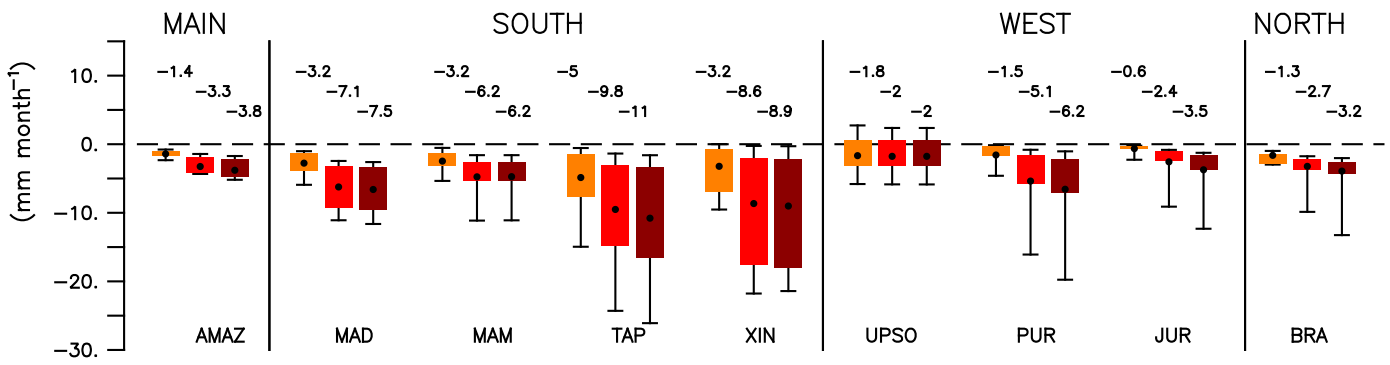

Figure 8. (a) Mean annual $\left(\mathrm{mm} \mathrm{yr}^{-1}\right)$ and (b) ASO values ( $\mathrm{mm} \mathrm{month}^{-1}$ ) of ET changes due to deforestation and assuming future climate change, for the end of the century, over the Amazon Basin and eight of its catchments (the abbreviations of the catchments are indicated in Table S1). Each box plot corresponds to the interquartile range (IQR, distance between the 25th and the 75th percentiles) within each catchment indicating the spread of the three GCM forcings $\times$ three LSMs results for one LCC scenario (see Fig. 6 for colour code). For a given box plot, the black points denote the mean value over the catchment, the whiskers extend from the minimum value to the maximum one and the numbers above the box plot indicate the mean relative differences over the catchment $(\%)$.

spread widely across all the simulations in these catchments $\left(\mathrm{IQR} \approx 430 \mathrm{~mm} \mathrm{yr}^{-1} ;\right.$ Fig. 3e).

\subsubsection{South-eastern catchments: ASO changes in ET and runoff}

During ASO, the end of the dry season in the south-eastern catchments, reduced precipitation causes a consistent decrease in ET, e.g. in the Xingu catchment by up to $8 \%$ $\left(10 \mathrm{~mm} \mathrm{month}^{-1}\right.$; Fig. $\left.3 \mathrm{~d}\right)$, where at least six out of nine simulations give a consistent ET reduction in many southern grid cells (Fig. 7b). The spread between all the projections simulating ET decrease is lower for the Tapajós than for the Xingu (IQR is 19 and $27 \mathrm{~mm} \mathrm{month}^{-1}$, respectively). Mean-ensemble runoff, already low during ASO in this region, decreases consistently by about $25 \%$ and the ensemble spread is low (IQR $<10 \mathrm{~mm} \mathrm{month}^{-1}$ ).

\subsection{Effects of deforestation (with background climate change)}

\subsubsection{Annual mean changes in ET and runoff}

Deforestation and climate change led to a consistent decrease in annual ET in the Amazon Basin by the end of the century of up to $2.6 \%$ (30 $\left.\mathrm{mm} \mathrm{yr}^{-1}\right)$ with the EXDEF scenario
(Fig. 8a). The resulting consistent increase of runoff is $2.2 \%$ (Fig. 9a) and both spreads of ET and runoff over the entire basin are small between the multiple forcings and LSMs used (IQR $=30 \mathrm{~mm} \mathrm{yr}^{-1}$ for runoff). With the EXDEF scenario, the loss of forest area leads to a continuous ET reduction throughout the 21 st century but of different magnitude depending on the simulation type (Fig. 10a). By the end of the 21 st century, ORCHIDEE simulates a $58 \mathrm{~mm} \mathrm{yr}^{-1}$ ET reduction while LPJmL-DGVM gives a decrease of $12 \mathrm{~mm} \mathrm{yr}^{-1}$ (multi-GCM forcing mean). In addition, for a given LSM, the decrease of ET differs according to the GCM forcing used, notably in the case of ORCHIDEE which simulates a decrease twice as large with UKMO-HadCM3 than with PCM. In EXDEF, ET is more strongly affected in the southern and eastern regions where forest area loss is important (compare Fig. S2f and c). A decrease in ET by up to $\sim 150 \mathrm{~mm} \mathrm{yr}^{-1}$ is obtained in these regions, where at least six out of nine simulations show a consistent ET decrease in the EXDEF scenario (Fig. 7c). In south-eastern catchments, the strong reduction of forest area in EXDEF leads to a consistent reduction of annual ET by up to $7 \%$ in the Tapajós catchment $\left(\sim 80 \mathrm{~mm} \mathrm{yr}^{-1}\right.$; Fig. $\left.8 \mathrm{a}\right)$ and to a consistent increase in runoff by $9 \%$ (Fig. 9a). In these two catchments, the spread within the ensemble is higher than in other regions (IQR $=80 \mathrm{~mm} \mathrm{yr}^{-1}$ for runoff increase in the Tapajós 
(a) Annual mean $\Delta R\left(m m \mathrm{yr}^{-1}\right)$

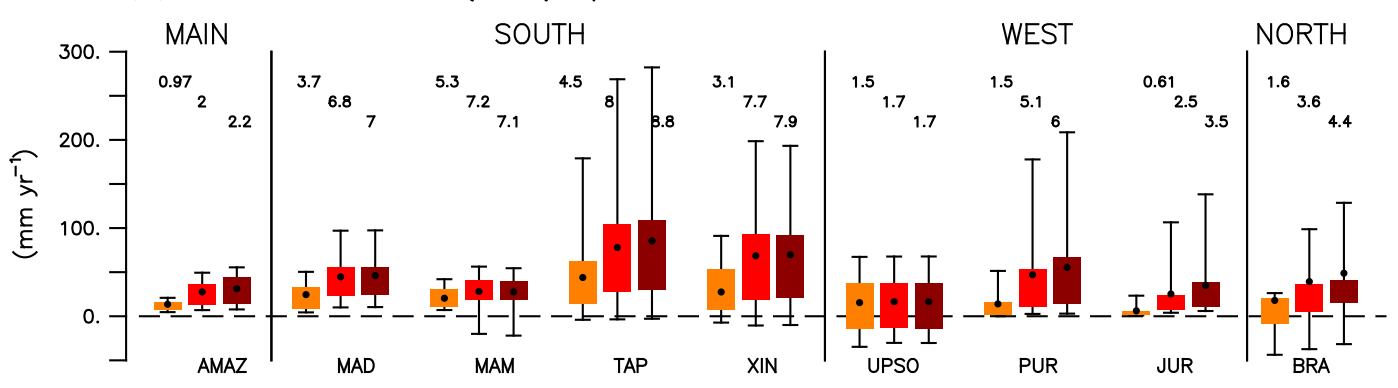

(b) ASO mean $\triangle R\left(m m\right.$ month $\left.^{-1}\right)$

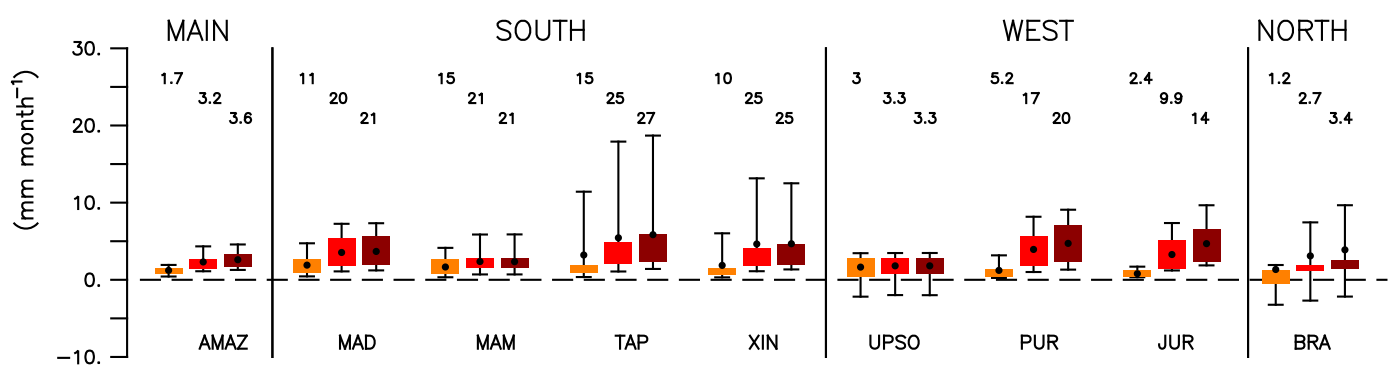

Figure 9. The same as Fig. 8 but for runoff.
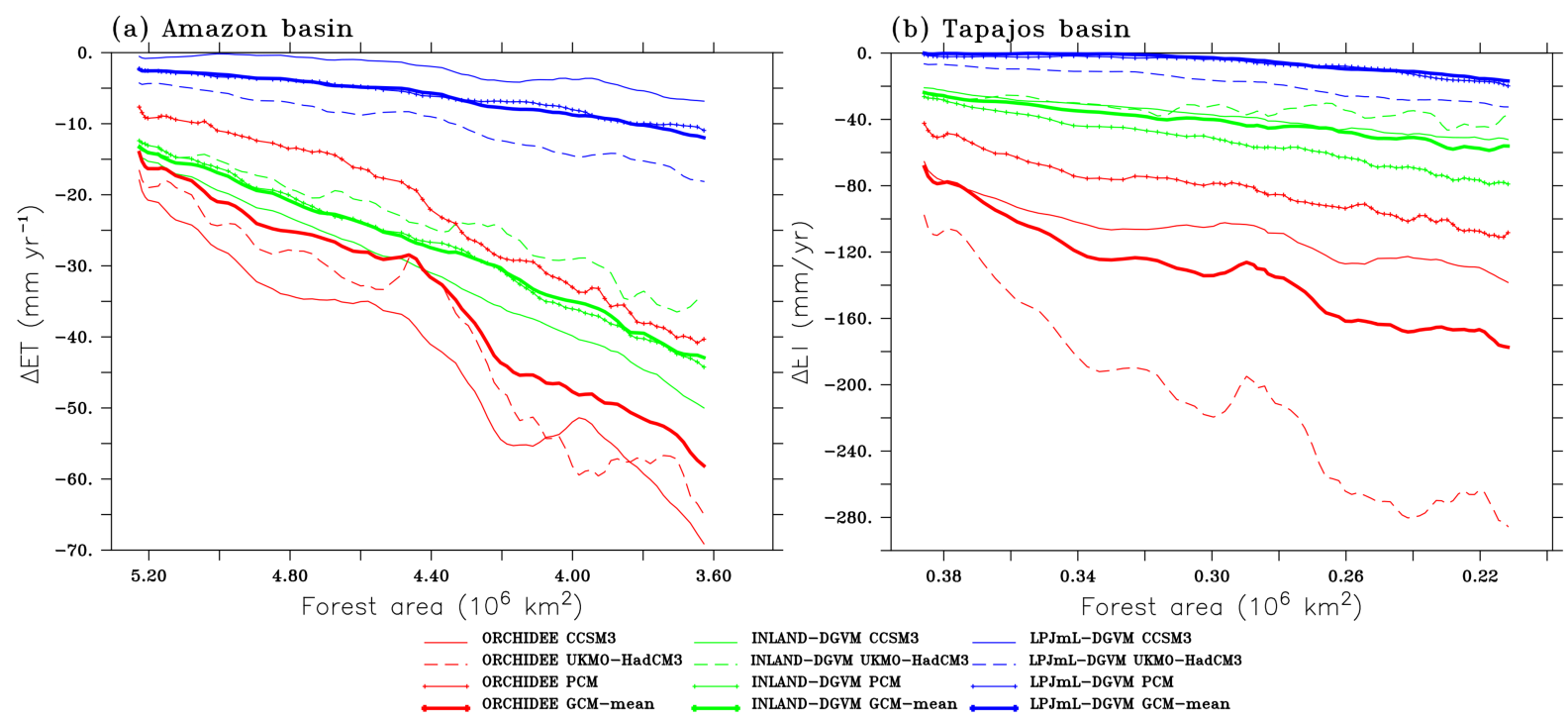

Figure 10. ET changes $\left(\mathrm{mm} \mathrm{yr}^{-1}\right)$ over 2009-2100 (1-year running mean) as a function of tree area decrease $\left(10^{6} \mathrm{~km}^{2}\right)$ from scenario EXDEF within the (a) Amazon and (b) Tapajós catchments.

catchment). In the western and northern catchments, deforestation induces a maximum consistent ET (runoff) reduction (increase) of less than $6.5 \%(6 \%)$ in each catchment.

\subsubsection{South-eastern catchments: ASO changes in ET and runoff}

During ASO in the south-eastern catchments, ensemblemean ET consistently decreases by up to $11 \%$ and runoff increases by up to $27 \%$ in the EXDEF scenario (Figs. $8 \mathrm{~b}$ and $9 \mathrm{~b}$ ). ORCHIDEE and INLAND-DGVM simulate the highest ET decreases in August over the Tapajós catchment (by 23 and $12 \mathrm{~mm} \mathrm{month}^{-1}$, respectively) while ET decreases most in October in LPJmL-DGVM $\left(-6.0 \mathrm{~mm} \mathrm{month}^{-1}\right)$ (Fig. S3c). Deforestation reduces both the evaporation of intercepted rainfall and transpiration by up to $45 \%$ during the wet season in ORCHIDEE (Fig. S4b), and increases soil evaporation by the same order of mag- 
nitude. In the Tapajós catchment, in the EXDEF scenario, LPJmL-DGVM exhibits strong water limitations and produces nearly no evaporation of intercepted rainfall, while the bare soil evaporation increases during the wet season. Over the Xingu catchment, ET reduction starts 1 month later in ORCHIDEE (1 month earlier in INLAND-DGVM) than in the Tapajós catchment, and seasonal variation of $\triangle \mathrm{ET}$ does not change with LPJmL-DGVM (Fig. S3d). Over the Madeira catchment, both ORCHIDEE and INLAND-DGVM simulate a small decrease in ET in the EXDEF simulations during the dry season (by up to $-10 \mathrm{~mm} \mathrm{month}^{-1}$ in August) while LPJmL-DGVM produces no change of ET (Fig. S3b). Changes in ET component fluxes have the same signs as in the Tapajós but smaller magnitudes (compare Fig. S4a and $b$ ).

\subsubsection{South-eastern catchments: uncertainties due to model structure}

Deforestation-induced ET variations during the dry season are driven by soil moisture changes which limit ET from dry soils (Juárez et al., 2007; Guimberteau et al., 2014). Thus, ET and runoff variations simulated by the LSMs are strongly linked to their soil hydrology and different soil moisture parameterizations, soil depths $(2,3$ and $4 \mathrm{~m}$ in the case of ORCHIDEE, LPJmL-DGVM and INLANDDGVM, respectively) and soil texture maps. Looking at specific model behaviour, e.g. during the dry season in the Tapajós catchment for the EXDEF scenario and CCSM3 forcing, we found that deforestation decreases soil moisture in the upper layers in ORCHIDEE and INLAND-DGVM (down to $50 \mathrm{~cm}$ and $2 \mathrm{~m}$, respectively) while deeper soil moisture increased in these two LSMs (Fig. 11a). These opposing changes of soil moisture in the soil profile are explained by the substitution of the deep-rooted forests by shallowrooted pasture and crops in the two LSMs (see de Rosnay and Polcher, 1998 for ORCHIDEE and Kucharik et al., 2000 for INLAND-DGVM). Short vegetation can only access water for transpiration from the near-surface layers. The resulting deforestation-induced ASO transpiration decrease is higher with ORCHIDEE $\left(\sim 30 \mathrm{~mm} \mathrm{month}^{-1}\right.$ in August) than INLAND-DGVM $\left(\sim 15 \mathrm{~mm} \mathrm{month}^{-1}\right.$ in the same month). Yet, in both conditions (with or without deforestation), INLAND-DGVM simulates higher ASO transpiration (Fig. 11a). This can be explained by the higher soil water holding capacity of INLAND-DGVM which enables this LSM to carry over more water from the wet season than ORCHIDEE. This helps to sustain the evaporation during the dry season, as reported by Guimberteau et al. (2014). The simulated leaf area index (LAI) being higher in INLANDDGVM than in ORCHIDEE can also explain the differences between the two LSMs in simulated ET (not shown). In contrast to both ORCHIDEE and INLAND-DGVM, transpiration with LPJmL-DGVM is strongly limited by water availability nearly all year round in southern Amazonia. As a re-

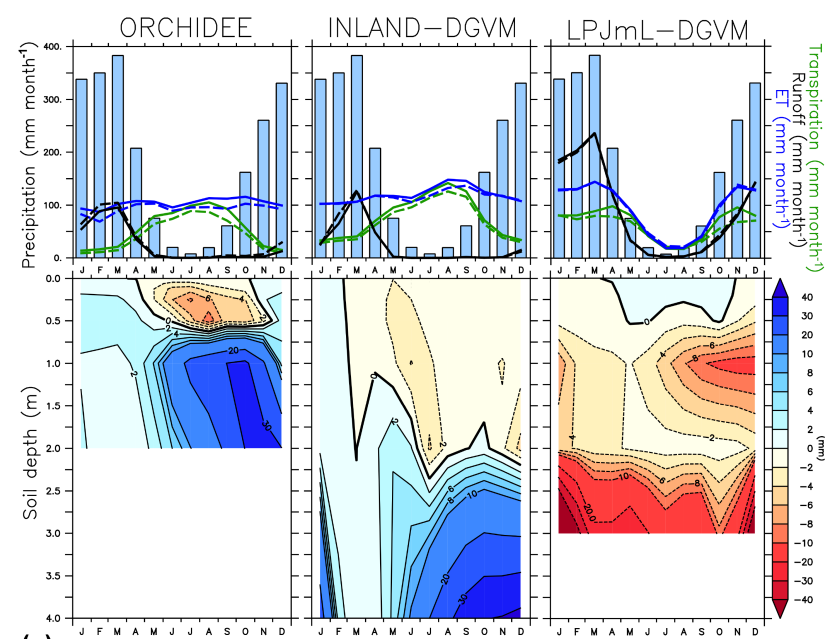

(a)

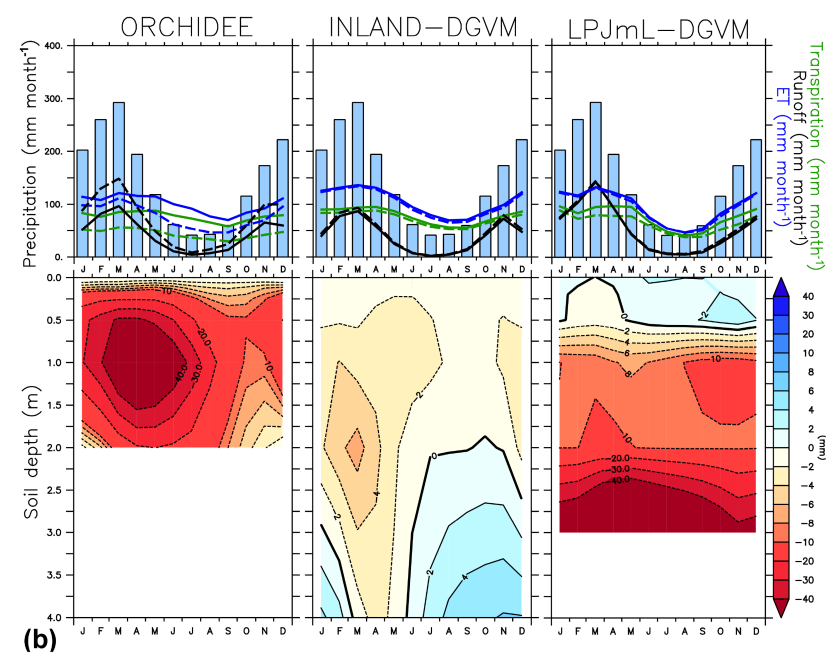

Figure 11. Impact of deforestation combined with climate change on ET (mm month $\left.{ }^{-1}\right)$, transpiration $\left(\mathrm{mm} \mathrm{month}^{-1}\right)$, runoff $\left(\mathrm{mm}\right.$ month $\left.^{-1}\right)$ and soil moisture $(\mathrm{mm})$ over the Tapajós catchment for the three LSMs for two different end-of-century climates: (a) CCSM3 and (b) UKMO-HadCM3. Top panels show seasonal cycle of precipitation $\left(\mathrm{mm} \mathrm{month}{ }^{-1}\right.$ ) with colour bars and seasonal cycles of ET, transpiration and runoff with plain/dashed lines for NODEF/EXDEF LCC scenarios. Bottom panels show corresponding change in soil moisture $(\mathrm{mm})$ due to deforestation combined with climate change. Results for PCM forcing are similar to those for CCSM3 forcing (not shown).

sult of this background limitation even without deforestation, under the EXDEF scenario, soil moisture in the deep layers of LPJmL-DGVM decreases only slightly all year long (by $\approx 10 \mathrm{~mm}$; Fig. 11a) and transpiration does not change during the dry season. 

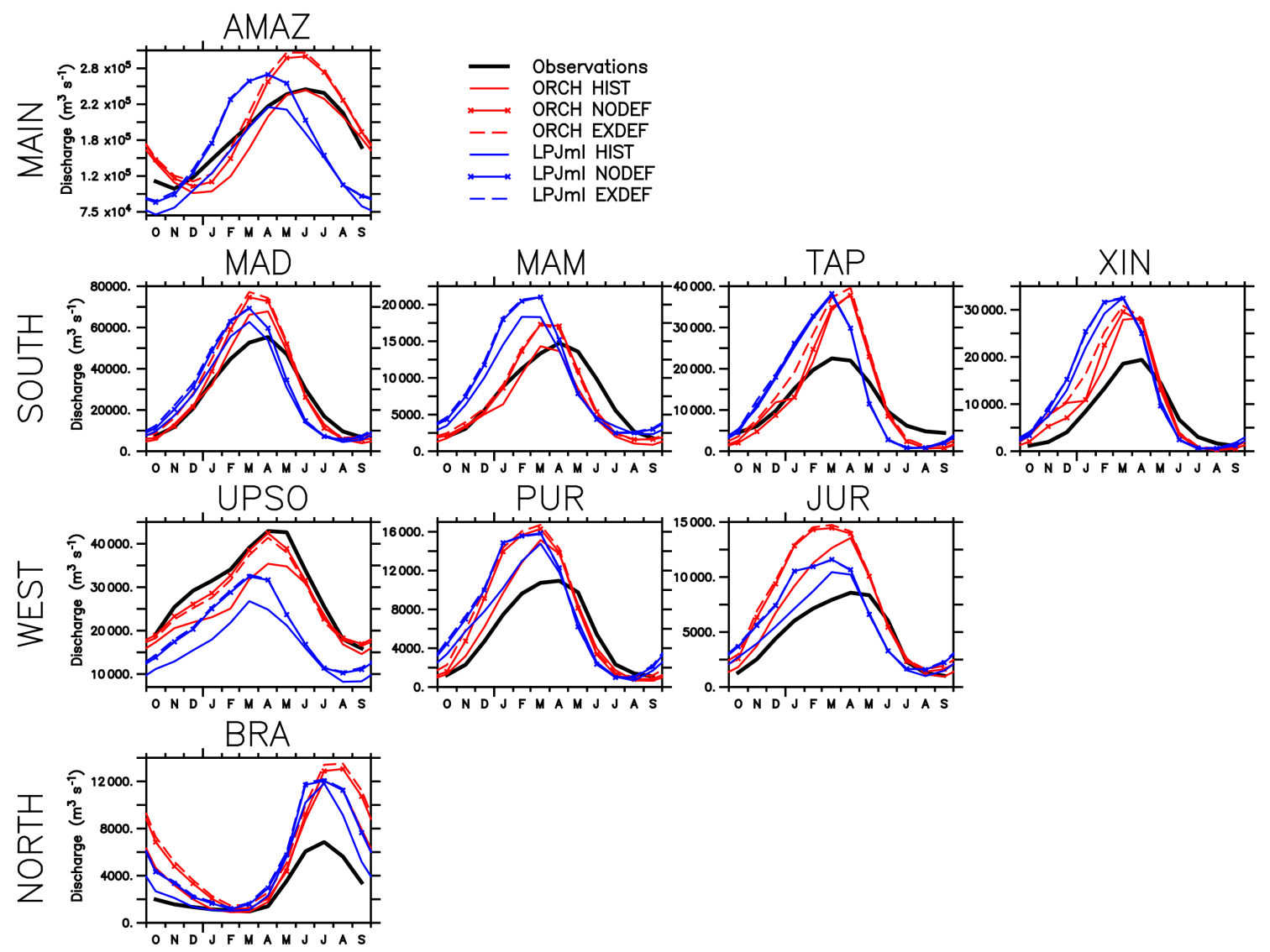

Figure 12. Seasonal river discharge $\left(\mathrm{m}^{3} \mathrm{~s}^{-1}\right)$ simulated by ORCHIDEE and LPJmL-DGVM from HIST (averaged over 1970-2008) and from NODEF and EXDEF LCC scenarios (mean of the three GCM forcings for each scenario averaged over 2080-2099) at the gauging stations over the Amazon catchments (the abbreviations of the catchments are indicated in Table S1). The results from HIST simulations are compared with the observations from the SO HYBAM (averaged over 1970-2008). River discharge is not represented for INLAND-DGVM because it does not include a routing scheme.

\subsubsection{South-eastern catchments: changes in soil moisture explained by GCM precipitation seasonality in presence of deforestation}

The amplitudes of the seasonal cycle of precipitation are different between the GCM forcings. In the UKMO-HadCM3 model, the seasonal amplitude is lower than in CCSM3 and PCM (compare Fig. 11a and b). In southern Amazonia, the CCSM3 precipitation drops by $79 \%\left(-300 \mathrm{~mm} \mathrm{month}^{-1}\right)$ between March (wettest month) and May (beginning of the dry season). By contrast, the precipitation drop between these two months is $60 \%\left(-180.0 \mathrm{~mm} \mathrm{month}^{-1}\right)$ in UKMOHadCM3. The influence of precipitation from the GCM forcings on the response of soil moisture variation to deforestation depends on the LSM considered. As a result, soil moisture is lower all year long with LPJmL-DGVM and ORCHIDEE forced by UKMO-HadCM3 due to the dry condition of the soil, even if the deforestation reduces ET. The largest soil moisture decrease occurs with ORCHIDEE from March to June, during the beginning of the dry season. Thus, the change in transpiration simulated by this LSM is highly sensitive to the difference in precipitation changes during the wet-to-dry transition period between CCSM3 and UKMOHadCM3.

\subsubsection{Changes in runoff and river discharge}

The increase of runoff simulated over the catchments translates into an increase of river discharge through the routing schemes of ORCHIDEE and LPJmL-DGVM (INLANDDGVM does not simulate river discharge). Because of the small effects of deforestation and climate change on the water budget of the entire Amazon Basin, changes in river discharge simulated by the LPJmL-DGVM, which is already dry in regions affected by deforestation (see above), are negligible for all the catchments (Fig. 12). The seasonal river discharge simulated by ORCHIDEE at Óbidos, the gauging station closest to the mouth of the Amazon Basin, is little affected by deforestation and climate change, with just a slight shift in the discharge increase between December and May. This is explained by an increase in runoff at the end of the dry 


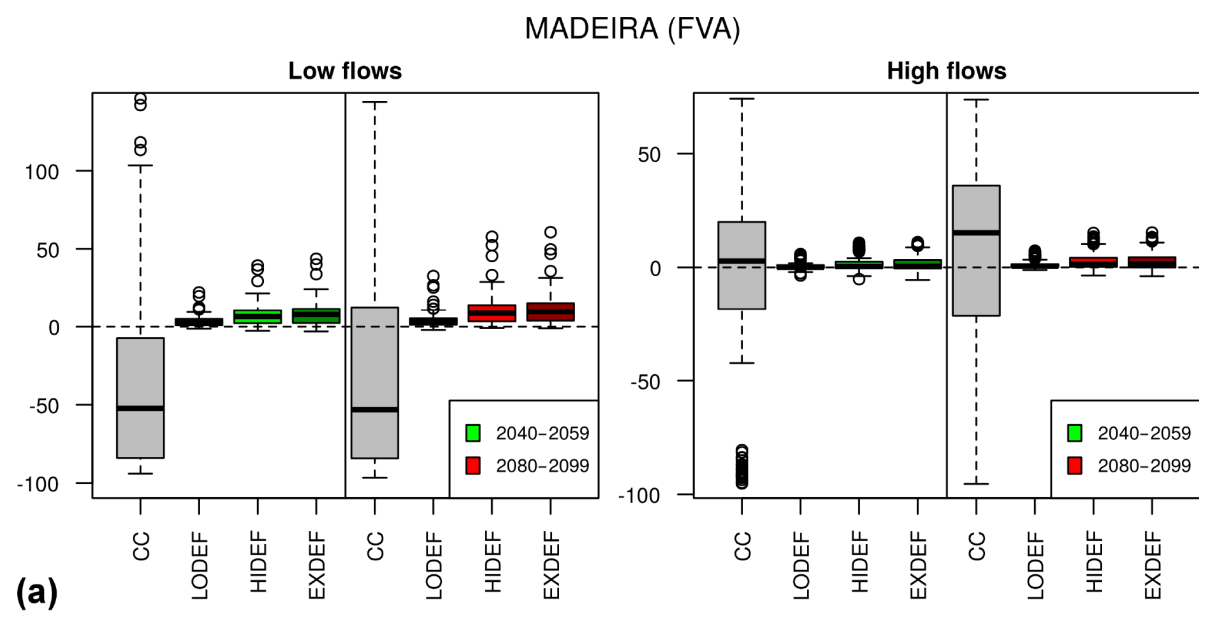

TAPAJOS (ITA)
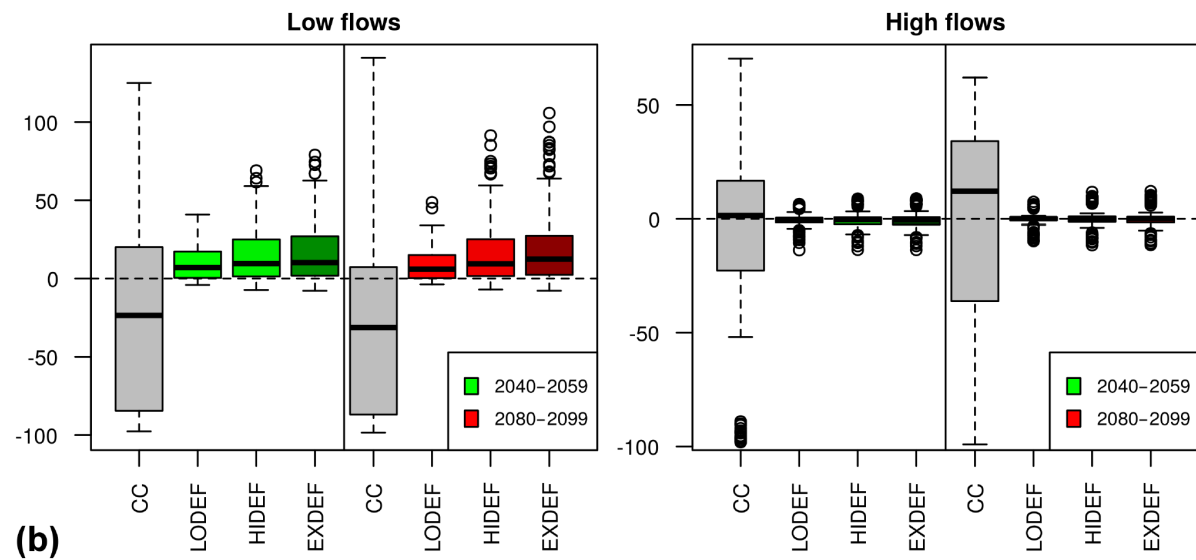

Figure 13. Relative change (\%) of the first deciles (i.e. low flow, left panels) and the last deciles (i.e. high flow, right panels) of river discharge due to climate change (grey) and deforestation combined to climate change (three LCC scenarios) of (a) the Madeira (at Fazenda Vista Alegre - FVA) and (b) the Tapajós (at Itaituba - ITA) for the middle (green) and the end (red) of the century. The changes are simulated by the ensemble of six simulations (two LSMs $\times$ three GCM forcings). The change of low flows and high flows cannot be represented with INLAND-DGVM because it does not include a routing scheme. The boxes correspond to the interquartile range (IQR, the distance between the 25 th and the 75 th percentiles), the bold horizontal line in each box is the median and the whiskers extend from the minimum value to the maximum value unless the distance from the minimum (maximum) value to the first (third) quartile is more than 1.5 times the IQR. Circles indicate the outliers that are $1.5 \times \mathrm{IQR}$ below (above) the 25 th percentile ( 75 th percentile).

season in the south (Madeira), where river discharge slightly increases between October and April.

The discharge extremes of the southern rivers (Madeira and Tapajós) are affected by deforestation (Fig. 13). The deforestation in the EXDEF scenario has an opposite effect compared to the effect of climate change on the low flows in both rivers. Namely, for the Madeira, the deforestationinduced increase of low flow ranges from 3.0 to $10 \%$, according to different LCC scenarios and compared to a climate-change-induced reduction by $50 \%$ (Fig. 13a). The high-flow increase in the Madeira due to deforestation is very small (up to $1.5 \%$ ) when compared to the climate change effect $(+15 \%)$. Yet, the spread of the results in the high-flow increase due to climate change is significantly reduced when taking the deforestation into account, suggesting some ro- bustness in the simulated impacts of deforestation on high flows. In the Tapajós catchment with the largest future forest area loss, high flows do not change with deforestation $(<0.5 \%)$, while climate change alone increases them by $12 \%$ but with a large spread (Fig. 13b). In contrast, with the deforestation, low flows consistently increase from 6 to $12.5 \%$ in the $2090 \mathrm{~s}$, depending on the LCC scenario. These changes are nearly half an order of magnitude as large as the effect of climate change $(-31 \%)$ suggesting that future deforestation is likely to balance the climate change impact on the hydrology of this catchment. 


\section{Discussion and synthesis}

\subsection{Does deforestation balance or amplify the impact of climate change on the hydrology of the Amazon Basin?}

Although with high uncertainties, greenhouse-gas-induced climate change will probably enhance the water cycle in Amazonia, increasing annual precipitation, ET and runoff by the end of the century. The three LSMs used in this study simulate an increase of ET, despite the physiological (antitranspirant) effect of increased $\mathrm{CO}_{2}$ being accounted for in all of them. However, this behaviour needs to be considered with caution, as it is obtained without considering atmospheric feedbacks. Considering the land-atmosphere coupling, deforestation may change precipitation recycling and thus the sign of the water balance over Amazonia (Coe et al., 2009). Consistent with Cook et al. (2012), Langerwisch et al. (2013), Guimberteau et al. (2013) and Sorribas et al. (2016), contrasted precipitation changes are projected between southern and western-northern regions. Comparing Figs. $4 \mathrm{~b}$ and $7 \mathrm{~b}$, the most pronounced decrease in ET occurs during the end of the dry season, in agreement with Lejeune et al. (2014), in regions where precipitation declines. ET decreases more than precipitation over all the south-eastern catchments (TAP and XIN); i.e. land surface processes incorporated in LSMs reduce the evaporated fraction of precipitation.

It has been suggested that a reduction in the area of Amazonian forest, such as that produced by the EXDEF scenario, will push much of Amazonia into a permanently drier climate regime (Malhi et al., 2008). At an annual scale, deforestationreduced ET only partly offsets the positive effect of climate change on ET even in EXDEF, so that all the simulations give a net increase of runoff by the end of the century. In southeastern Amazonia, the $\sim 50 \%$ forest area loss in EXDEF combined with climate change leads to a consistent ET decrease which offsets positive changes of ET due to climate change alone. Over the Xingu, our projections of the hydrological budget are consistent with Panday et al. (2015), who also found opposite effects of deforestation and climate during the past 40 years using a combination of long-term observations of rainfall and discharge. Yet, our settings of constant land use ignore the influence of historic deforestation on ET and may result in highly biased estimates of deforestation effects on ET.

Generally, the resulting increase of runoff after deforestation is consistent with other studies, such as LCC simulations with LSMs at the global scale (Sterling et al., 2013) and LCC experiments on watersheds in the northern Appalachians where water yields increase after intensive cuttings (Rothacher, 1970; Hornbeck et al., 2014). The increase of annual runoff in the Xingu catchment $(+8 \%)$, with increasing deforestation in the future, is of similar order to the results of Stickler et al. (2013), who found a 10 to $12 \%$ runoff increase given $40 \%$ deforestation in this catchment. Yet, during ASO in the south-eastern catchments, deforestation amplifies the effect of climate change in reducing ET, in particular in the south of the Tapajós catchment and in the north of the Madeira and Xingu catchments where deforested areas are the largest. Thus, deforestation contributes to the increase in runoff $(+27 \%$ in the Tapajós) and thus balances the runoff-reducing effect of climate change $(-22 \%$ in the Tapajós).

\subsection{Consequences on the extreme discharge of the southern rivers}

The ET decrease and runoff increase projected for southern catchments (Madeira and Tapajós) by the extreme deforestation scenario applied here (EXDEF) balances the climate change effect on low flows. Climate change alone increases the seasonal amplitude of discharge and high-flow values. In contrast, deforestation balances this effect by reducing the risk of decrease in low flows in the Madeira and Tapajós in all LCC scenarios; this is related to the decrease of ET during the dry season. The low-flow increase of the Tapajós is consistent with higher future discharge during the dry season, in the Jamanxim subcatchment (lower Tapajós) (Lamparter et al., 2016). Our result for the Madeira contradicts those of Siqueira Júnior et al. (2015) who found a decrease of low flows with the hydrological model MHD-INPE, combined with the business-as-usual scenario (BAU) of SoaresFilho et al. (2006) where deforestation is lower than in the EXDEF scenario. They argue that this behaviour is due to the occurrence of faster flows when deforestation is taken into account, even though this contradicts the fact that LCC scenarios are associated with reduced ET. This comparison highlights the uncertainty in the results of the effect of deforestation on hydrology, depending on whether we use LSMs or hydrological models to simulate river discharge.

\subsection{Contributions of GCMs, LSMs and land cover change scenarios to total uncertainty in ET and runoff projections}

ET and runoff projections are associated with large uncertainties, although the projected sign of change is usually robust regarding deforestation. Large climate change uncertainty, consistent with previous studies (Li et al., 2006; Vera et al., 2006; Torres and Marengo, 2013), occurs in the southern water-limited regions of the Madeira, Xingu and Tapajós catchments (between 38 and $83 \%$ ). The magnitude of the ET changes due to climate change alone is more uncertain than that induced by the deforestation in the three LSMs assessed. During the wet-to-dry transition period, the strength of the precipitation decrease driven by climate change determines the change of soil water storage due to deforestation, which sustains the evaporation during the dry season. 

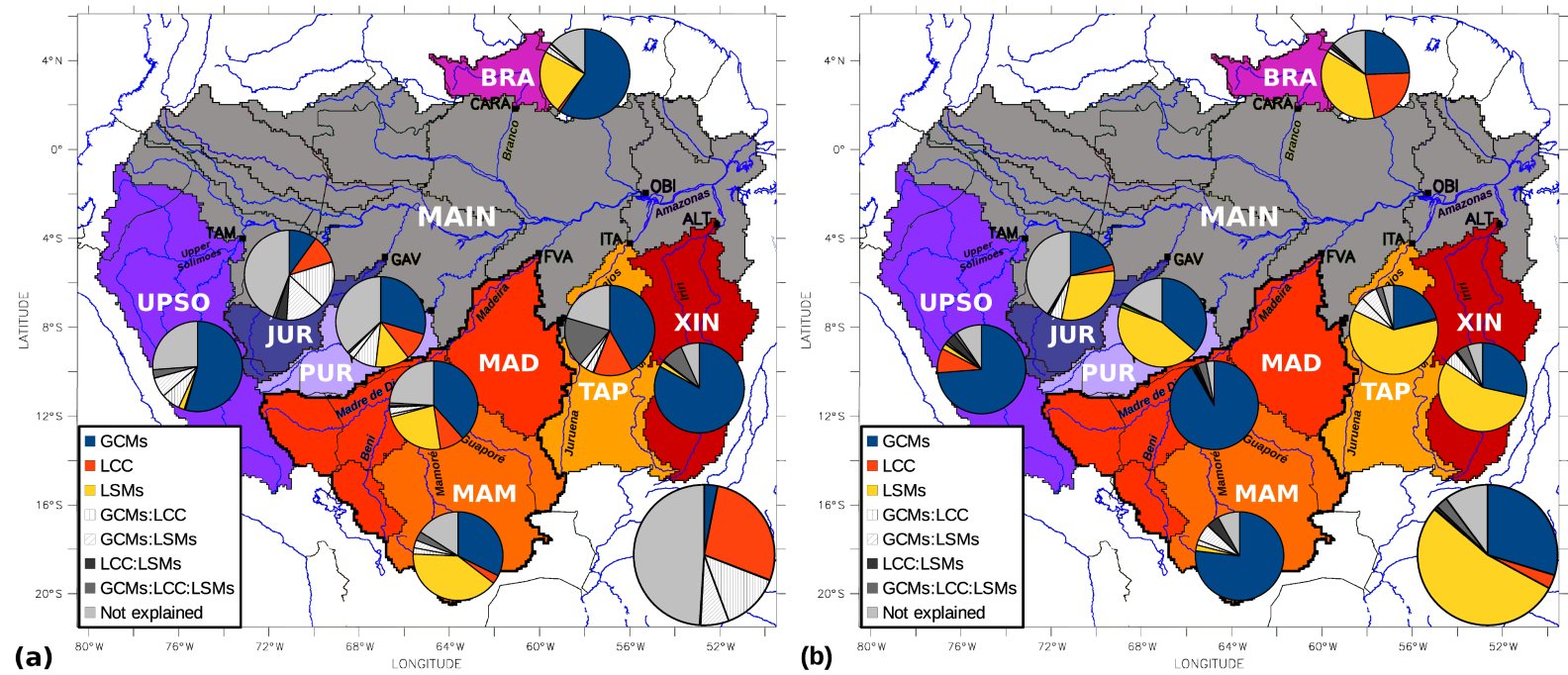

Figure 14. Contributions of GCMs, LCC scenarios, LSMs and interactions between each to total uncertainty in (a) ET and (b) runoff changes, for the end of the century, for the Amazon Basin (bottom right pie chart) and eight of its catchments.

To further distinguish and quantify the uncertainties which originate from the GCMs, LSMs and the LCC scenarios, we used ANOVA. We found that the main uncertainty source is different for ET (Fig. 14a) and runoff (Fig. 14b). On average, over the entire Amazon Basin (OBI), LCC provides the largest uncertainty for ET projections (38\% of total uncertainty) but most of the ET variance is unexplained by the studied factors. At the subcatchment scale, in contrast, the ANOVA method identifies the GCMs as the dominant uncertainty source for ET projections. Significant interactions between GCMs and LCC scenarios also occur in the western catchments, suggesting that these contributions do not behave linearly. Large uncertainties due to LSMs are also found in the southern catchments.

Regarding runoff (Fig. 14b), the overall uncertainty is dominated by the LSMs' contribution (53\%), particularly in the Xingu and Tapajós catchments $(60 \%)$, suggesting the difficulty of these models to simulate contrasted runoff variations that naturally occur during the year in these catchments. Uncertainty in the simulated runoff changes attributable to LCC only occurs in the Branco catchment (22\%), while it is largely attributable to GCMs in southern (up to $91 \%$ in the Madeira) and western (73\% in the upper Solimões) catchments.

In summary, at the subcatchment scale, the magnitude of the changes in ET first depends on GCMs and then on the behaviour of each LSM (water-limited versus energy-limited models) in the southern catchments. Conversely, uncertainty in runoff changes in the Amazon Basin (OBI) is first attributable to LSMs, particularly in the south-eastern catchments, and then to GCMs. The uncertainty attributable to LCC is low in these catchments, suggesting some robustness in the response of the hydrology to the deforestation.
Thus, our study emphasizes the uncertainty associated with the choice of the LSMs and their inherent (energy-limited or water-limited) parameterizations in the estimation of deforestation impacts on runoff. Over large river basins like the Amazon, these models have the disadvantage of being rather poorly constrained in their parameterizations of both vegetation functioning (Poulter et al., 2010) and soil hydrology (Christoffersen et al., 2014). In our view, the LSM community needs to strengthen its efforts to cooperate with the soil science community to improve the representation of soil hydrological processes in their models, despite the difference in scale at which they work and the inherent small-scale variability of soil properties.

\section{Conclusions}

The construction of new land-cover change scenarios for Amazonia indicates that, by the end of this century, the total forested area of the Amazon Basin will have decreased by $7 \%$ in the best case to $34 \%$ in the most severe scenario. The most severe forest clearing occurs in southern Amazonia where the Madeira, Xingu and Tapajós catchments experience a $50 \%$ decrease in forest area. With a multi-model approach, we found that the replacement of the forests by pasture and crops should only slightly decrease annual evapotranspiration by up to $2.5 \%$ and enhance runoff by up to $2.2 \%$, for the most severe scenario of the Amazon Basin, compared to simulations with climate change only.

The south-eastern catchments, however, are more vulnerable at the end of the dry season. Compared to forest, crops and pastures fail to sustain their evaporation in a high drought stress context. Given the combination of decreased rainfall due to future climate change and the large forest area loss, 
evapotranspiration may drop by -9 and $-11 \%$ in the Xingu and Tapajós catchments, respectively, with deforestation amplifying the decrease of ET due to climate change alone. The dominant uncertainty associated with these results comes from the climate change scenarios. In contrast, by enhancing the runoff, the deforestation balances the negative effect of climate change on runoff in these catchments. As a result, the deforestation in the most intensive scenario balances the risk of decrease in low flows of the Tapajós due to climate change by the end of the century. In these catchments, LSMs are the largest uncertainty source for runoff projections, while the climate change uncertainty dominates in the southern catchments (Madeira and Mamoré). Our results in the Tapajós catchment emphasize the impact of deforestation combined with climate change on hydrological extremes. The deforestation leads to a $12.5 \%$ increase in low flows by the end of the century, which balances the opposite impact of climate change.

Biosphere-atmosphere interactions, not accounted for in our study, are also crucial in estimating the progress of forest dieback, whereby forest is replaced by savanna vegetation. During the end of the dry season, we found a strong reduction of ET in south-eastern Amazonia. Evaporation at this time of year provides a critical source of water vapour for precipitation, and lower ET can delay the onset of the wet season (Fu and $\mathrm{Li}, 2004$ ) and reduce the water recycling during this period (Lima et al., 2014). We need to pay careful attention to the intensification and lengthening of droughts during this century, a phenomenon that is commonly predicted by the GCMs for southern Amazonia (Boisier et al., 2015). Whatever its cause, our results emphasize the need to include the deforestation process in climate change simulations. Deforestation has the potential to mask (or unmask) the effects of climate change on surface hydrology.

Code and data availability. The version of the ORCHIDEE model used for this study is Trunk.rev1311. The source code of the ORCHIDEE model can be obtained upon request (see http: //labex.ipsl.fr/orchidee/index.php/contact). Documentation on the code, including scientific and technical aspects, is available here: https://vesg.ipsl.upmc.fr/thredds/fileServer/IPSLFS/orchidee/ DOXYGEN/webdoc_2425/index.html.

\section{The Supplement related to this article is available online at doi:10.5194/hess-21-1455-2017-supplement.}

Competing interests. The authors declare that they have no conflict of interest.

Acknowledgements. This work was financially supported by the EU-FP7 AMAZALERT (Raising the alert about critical feedbacks between climate and long-term land-use change in the Amazon) project (grant agreement no. 282664) and the European Research Council Synergy grant ERC-2013-SyG-610028 IMBALANCE-P.
We acknowledge the SO HYBAM team which provided their river flow data sets for the Amazon Basin (http://www.ore-hybam.org). Simulations with ORCHIDEE were performed using computational facilities of the Institut du Déeloppement et des Ressources en Informatique Scientifique (IDRIS, CNRS, France). The authors gratefully acknowledge John Gash for proofreading and correcting the English edition of the manuscript.

Edited by: F. Fenicia

Reviewed by: T. Roy and two anonymous referees

\section{References}

Aguiar, A. P. D., Ometto, J. P., Nobre, C., Lapola, D. M., Almeida, C., Vieira, I. C., Soares, J. V., Alvala, R., Saatchi, S., Valeriano, D., and Castilla-Rubio, J. C.: Modeling the spatial and temporal heterogeneity of deforestation-driven carbon emissions: the INPE-EM framework applied to the Brazilian Amazon, Global Change Biol., 18, 3346-3366, 2012.

Aguiar, A. P. D., Vieira, I. C. G., Assis, T. O., Dalla-Nora, E. L., Toledo, P. M., Oliveira Santos-Junior, R. A., Batistella, M., Coelho, A. S., Savaget, E. K., Aragão, L. E. O. C., Nobre, C. A., and Ometto, J.-P. H.: Land use change emission scenarios: anticipating a forest transition process in the Brazilian Amazon?, Global Change Biol., 22, 1821-1840, doi:10.1111/gcb.13134, 2016.

Alcamo, J. (Ed.): Chapter Six. The SAS Approach: Combining Qualitative and Quantitative Knowledge in Environmental Scenarios, in: Environmental Futures The Practice of Environmental Scenario Analysis, vol. 2 of Developments in Integrated Environmental Assessment, Elsevier, Amsterdam, the Netherlands, 123150, doi:10.1016/S1574-101X(08)00406-7, 2008.

Alves, D. S.: Space-time dynamics of deforestation in Brazilian Amazonia, Int. J. Remote Sens., 23, 2903-2908, 2002.

Assunção, J., Gandour, C. C., and Rocha, R.: Deforestation slowdown in the Legal Amazon: prices or policies, Clim. Policy Initiat., 1, 03-37, 2012.

Barni, P. E., Pereira, V. B., Manzi, A. O., and Barbosa, R. I.: Deforestation and forest fires in Roraima and their relationship with phytoclimatic regions in the Northern Brazilian Amazon, Environ. Manage., 55, 1124-1138, 2015.

Becker, B. K.: Amazônia, 5th Edn., editions Atica, Sao Paulo, p. 112, 1997.

Becker, B. K.: Amazônia: geopolítica na virada do III milênio, Editora Garamond, Rio de Janeiro, Brazil, 2004.

Biemans, H., Hutjes, R., Kabat, P., Strengers, B., Gerten, D., and Rost, S.: Effects of precipitation uncertainty on discharge calculations for main river basins, J. Hydrometeorol., 10, 1011-1025, 2009.

Boisier, J.-P., Ciais, P., Ducharne, A., and Guimberteau, M.: Projected strengthening of Amazonian dry season by constrained climate model simulations, Nat. Clim. Change, 5, 656-660, 2015.

Bonan, G. B., Oleson, K. W., Vertenstein, M., Levis, S., Zeng, X., Dai, Y., Dickinson, R. E., and Yang, Z.-L.: The land surface climatology of the community land model coupled to the NCAR community climate model, J. Climate, 15, 3123-3149, 2002.

Boucher, D., Roquemore, S., and Fitzhugh, E.: Brazil's success in reducing deforestation, Trop. Conserv. Sci., 6, 426-445, 2013. 
Callède, J., Ronchail, J., Guyot, J., and Oliveira, E.: Déboisement amazonien: son influence sur le débit de l'Amazone à Óbidos (Brésil), Rev. Sci. Eau, 21, 59-72, 2008.

Christoffersen, B. O., Restrepo-Coupe, N., Arain, M. A., Baker, I. T., Cestaro, B. P., Ciais, P., Fisher, J. B., Galbraith, D., Guan, X., Gulden, L., van den Hurk, B., Ichii, K., Imbuzeiro, H., Jain, A., Levine, N., Miguez-Macho, G., Poulter, B., Roberti, D., Sakaguchi, K., Sahoo, A., Schaefer, K., Shi, M., Verbeeck, H., Yang, Z.-L., Araujo, A. C., Kruijt, B., Manzi, A. O., da Rocha, H. R., von Randow, C., Muza, M. N., Borak, J., Costa, M. H., de Goncalves, L. G. G., Zeng, X., and Saleska, S. R.: Mechanisms of water supply and vegetation demand govern the seasonality and magnitude of evapotranspiration in Amazonia and Cerrado, Agr. Forest Meteorol., 191, 33-50, 2014.

Coe, M., Costa, M., and Soares-Filho, B.: The influence of historical and potential future deforestation on the stream flow of the Amazon River-Land surface processes and atmospheric feedbacks, J. Hydrol., 369, 165-174, 2009.

Cook, B., Zeng, N., and Yoon, J.: Will Amazonia dry out: Magnitude and Causes of change from IPCC climate model projections, Earth Interact., 16, 1-27, 2012.

Costa, M. H. and Pires, G. F.: Effects of Amazon and Central Brazil deforestation scenarios on the duration of the dry season in the arc of deforestation, Int. J. Climatol., 30, 1970-1979, 2010.

Covey, C., AchutaRao, K. M., Cubasch, U., Jones, P., Lambert, S. J., Mann, M. E., Phillips, T. J., and Taylor, K. E.: An overview of results from the Coupled Model Intercomparison Project, Global Planet. Change, 37, 103-133, 2003.

Cox, P. M., Betts, R., Collins, M., Harris, P., Huntingford, C., and Jones, C.: Amazonian forest dieback under climate-carbon cycle projections for the 21 st century, Theor. Appl. Climatol., 78, 137156, 2004.

Dalla-Nora, E. L., de Aguiar, A. P. D., Lapola, D. M., and Woltjer, G.: Why have land use change models for the Amazon failed to capture the amount of deforestation over the last decade?, Land Use Policy, 39, 403-411, 2014.

de Rosnay, P. and Polcher, J.: Modelling root water uptake in a complex land surface scheme coupled to a GCM, Hydrol. Earth Syst. Sci., 2, 239-255, doi:10.5194/hess-2-239-1998, 1998.

Dias, L. C. P., Macedo, M. N., Costa, M. H., Coe, M. T., and Neill, C.: Effects of land cover change on evapotranspiration and streamflow of small catchments in the Upper Xingu River Basin, Central Brazil, J. Hydrol. Reg. Stud., 4, 108-122, 2015.

Eupen, V. M., Cormont, A., Kok, K., Simoes, M., Pereira, R., and Kolb, M.: D2. 2.1 Modelling Land Use Change in Latin America, EU, 2014 (Deliverable 2.2.1), Public report: Deliverable 2.2.1 EU-FP7 Collaborative Project number: 283093, ROBIN project, Wageningen, the Netherlands, p. 70, available at: http://robinproject.info/home/products/deliverables-2/ (last access: 10 May 2016), 2014.

Fearnside, P. M.: Deforestation in Brazilian Amazonia: history, rates, and consequences, Conserv. Biol., 19, 680-688, 2005.

Foley, J. A., Prentice, I. C., Ramankutty, N., Levis, S., Pollard, D., Sitch, S., and Haxeltine, A.: An integrated biosphere model of land surface processes, terrestrial carbon balance, and vegetation dynamics, Global Biogeochem. Cy., 10, 603-628, 1996.

$\mathrm{Fu}, \mathrm{R}$. and Li, W.: The influence of the land surface on the transition from dry to wet season in Amazonia, Theor. Appl. Climatol., 78, 97-110, 2004.
Gash, J. H. C., Huntingford, C., Marengo, J. A., Betts, R. A., Cox, P. M., Fisch, G., Fu, R., Gandu, A. W., Harris, P. P., Machado, L. A. T., von Randow, C., and Dias, M. A. S.: Amazonian climate: results and future research, Theor. Appl. Climatol., 78, 187-193, doi:10.1007/s00704-004-0052-9, 2004.

Giuntoli, I., Vidal, J.-P., Prudhomme, C., and Hannah, D. M.: Future hydrological extremes: the uncertainty from multiple global climate and global hydrological models, Earth Syst. Dynam., 6, 267-285, doi:10.5194/esd-6-267-2015, 2015.

Gordon, C., Cooper, C., Senior, C. A., Banks, H., Gregory, J. M., Johns, T. C., Mitchell, J. F., and Wood, R. A.: The simulation of SST, sea ice extents and ocean heat transports in a version of the Hadley Centre coupled model without flux adjustments, Clim. Dynam., 16, 147-168, 2000.

Guimberteau, M., Drapeau, G., Ronchail, J., Sultan, B., Polcher, J., Martinez, J. M., Prigent, C., Guyot, J. L., Cochonneau, G., Espinoza, J. C., Filizola, N., Fraizy, P., Lavado, W., De Oliveira, E., Pombosa, R., Noriega, L., and Vauchel, P.: Discharge simulation in the sub-basins of the Amazon using ORCHIDEE forced by new datasets, Hydrol. Earth Syst. Sci., 16, 911-935, doi:10.5194/hess-16-911-2012, 2012.

Guimberteau, M., Ronchail, J., Espinoza, J. C., Lengaigne, M., Sultan, B., Polcher, J., Drapeau, G., Guyot, J. L., Ducharne, A., and Ciais, P.: Future changes in precipitation and impacts on extreme streamflow over Amazonian sub-basins, Environ. Res. Lett., 8, 014035, doi:10.1088/1748-9326/8/1/014035, 2013.

Guimberteau, M., Ducharne, A., Ciais, P., Boisier, J.-P., Peng, S., De Weirdt, M., and Verbeeck, H.: Testing conceptual and physically based soil hydrology schemes against observations for the Amazon Basin, Geosci. Model Dev., 7, 1115-1136, doi:10.5194/gmd-7-1115-2014, 2014.

Hornbeck, J. W., Bailey, A. S., Eager, C., and Campbell, J. L.: Comparisons with results from the Hubbard Brook Experimental Forest in the northern Appalachians, Long-term response of a forest watershed ecosystem, in: Clearcutting in the southern Appalachians, Oxford University Press, Oxford, 213-228, 2014.

Huffman, G., Adler, R., Morrissey, M., Bolvin, D., Curtis, S., Joyce, R., McGavock, B., and Susskind, J.: Global precipitation at onedegree daily resolution from multisatellite observations, J. Hydrometeorol., 2, 36-50, 2001.

Huffman, G., Bolvin, D., Nelkin, E., Wolff, D., Adler, R., Gu, G., Hong, Y., Bowman, K., and Stocker, E.: The TRMM multisatellite precipitation analysis (TMPA): Quasi-global, multiyear, combined-sensor precipitation estimates at fine scales, J. Hydrometeorol., 8, 38-55, 2007.

INPE: Annual deforestation rates recorded in the Brazilian Amazon since 1988, Tech. rep., Brazilian National Institute for Space Research, São Paulo, Brazil, 2016.

IPCC: Climate Change 2013: The Physical Science Basis. Contribution of Working Group I to the Fifth Assessment Report of the Intergovernmental Panel on Climate Change, Cambridge University Press (CUP), doi:10.1017/cbo9781107415324, 2013.

Juárez, R. I. N., Hodnett, M. G., Fu, R., Goulden, M. L., and von Randow, C.: Control of dry season evapotranspiration over the Amazonian forest as inferred from observations at a southern Amazon forest site, J. Climate, 20, 2827-2839, 2007.

Kay, G., Alves, L., Betts, R., Boisier, J.-P., Boorman, P., Cardoso, M., Ciais, P., de Noblet-Ducoudre, N., Dolman, H., Joetzjer, E., Jones, C., Halladay, K., Marengo, J., Mathison, C., Meesters, A., 
Nobre, C., Sampaio, G., and Seiler, C.: Report on impacts of climate change and IPCC RCP land use scenarios in Earth System Models, Tech. Rep., AMAZALERT Delivery Report WP3, Delivery 3.1, AMAZALERT project, Wageningen, the Netherlands, 2013.

Keller, M., Bustamante, M., Gash, J., and Dias, P. S.: Amazonia and Global Change, Geophys. Monogr. Ser., vol. 186, AGU, Washington, D.C., 2009.

Killeen, T., Soria, L., Quezada, B., Guerra, A., Calderon, V., Clazadilla, M., and Steininger, M.: Mapa de Cobertura de la Tierra y Deforestacion hasta 2008, Museum of Natural History Noel Kempff Mercado, Santa Cruz, Bolivia, 2012.

Kistler, R., Kalnay, E., Collins, W., Saha, S., White, G., Woollen, J., Chelliah, M., Ebisuzaki, W., Kanamitsu, M., Kousky, V., van den Dool, H., Jenne, R., and Fiorino, M.: The NCEP-NCAR 50year reanalysis: Monthly means CD-ROM and documentation, B. Am. Meteorol. Soc., 82, 247-267, 2001.

Krinner, G., Viovy, N., de Noblet-Ducoudre, N., Ogee, J., Polcher, J., Friedlingstein, P., Ciais, P., Sitch, S., and Prentice, I.: A dynamic global vegetation model for studies of the coupled atmosphere-biosphere system, Global Biogeochem. Cy., 19, 133, doi:10.1029/2003GB002199, 2005.

Kucharik, C. J., Foley, J. A., Delire, C., Fisher, V. A., Coe, M. T., Lenters, J. D., Young-Molling, C., Ramankutty, N., Norman, J. M., and Gower, S. T.: Testing the performance of a dynamic global ecosystem model: water balance, carbon balance, and vegetation structure, Global Biogeochem. Cy., 14, 795-825, 2000.

Lamparter, G., Nobrega, R. L. B., Kovacs, K., Amorim, R. S., and Gerold, G.: Modelling hydrological impacts of agricultural expansion in two macro-catchments in Southern Amazonia, Brazil, Reg. Environ. Change, doi:10.1007/s10113-016-1015-2, in press, 2016.

Langerwisch, F., Rost, S., Gerten, D., Poulter, B., Rammig, A., and Cramer, W.: Potential effects of climate change on inundation patterns in the Amazon Basin, Hydrol. Earth Syst. Sci., 17, 22472262, doi:10.5194/hess-17-2247-2013, 2013.

Lapola, D. M., Schaldach, R., Alcamo, J., Bondeau, A., Msangi, S., Priess, J. A., Silvestrini, R., and Soares-Filho, B. S.: Impacts of climate change and the end of deforestation on land use in the Brazilian Legal Amazon, Earth Interact., 15, 1-29, 2011.

Laurance, W. F., Cochrane, M. A., Bergen, S., Fearnside, P. M., Delamônica, P., Barber, C., D'Angelo, S., and Fernandes, T.: The future of the Brazilian Amazon, Science, 291, 438-439, 2001.

Lejeune, Q., Davin, E. L., Guillod, B. P., and Seneviratne, S. I.: Influence of Amazonian deforestation on the future evolution of regional surface fluxes, circulation, surface temperature and precipitation, Clim. Dynam., 44, 2769-2786, 2014.

Li, W., Fu, R., and Dickinson, R.: Rainfall and its seasonality over the Amazon in the 21st century as assessed by the coupled models for the IPCC AR4, J. Geophys. Res.-Atmos., 111, D02111, doi:10.1029/2005JD006355, 2006.

Lima, L. S., Coe, M. T., Soares Filho, B. S., Cuadra, S. V., Dias, L. C., Costa, M. H., Lima, L. S., and Rodrigues, H. O.: Feedbacks between deforestation, climate, and hydrology in the Southwestern Amazon: implications for the provision of ecosystem services, Landsc. Ecol., 29, 261-274, 2014.

Lyra, A. D. A., Chou, S. C., and Sampaio, G. D. O.: Sensitivity of the Amazon biome to high resolution climate change projections, Acta Amazon., 46, 175-188, 2016.
Macedo, M. N., DeFries, R. S., Morton, D. C., Stickler, C. M., Galford, G. L., and Shimabukuro, Y. E.: Decoupling of deforestation and soy production in the southern Amazon during the late 2000s, P Natl. Acad. Sci. USA, 109, 1341-1346, doi:10.1073/pnas.1111374109, 2012.

Malhi, Y., Roberts, J., Betts, R., Killeen, T., Li, W., and Nobre, C.: Climate change, deforestation, and the fate of the Amazon, Science, 319, 169-172, 2008.

Malhi, Y., Aragão, L. E., Galbraith, D., Huntingford, C., Fisher, R., Zelazowski, P., Sitch, S., McSweeney, C., and Meir, P.: Exploring the likelihood and mechanism of a climate-change-induced dieback of the Amazon rainforest, P. Natl. Acad. Sci. USA, 106, 20610-20615, 2009.

Malingreau, J., Eva, H., and De Miranda, E.: Brazilian Amazon: a significant five year drop in deforestation rates but figures are on the rise again, Ambio, 41, 309-314, 2012.

Moghim, S., McKnight, S. L., Zhang, K., Ebtehaj, A. M., Knox, R. G., Bras, R. L., Moorcroft, P. R., and Wang, J.: Bias-corrected data sets of climate model outputs at uniform space-time resolution for land surface modelling over Amazonia, Int. J. Climatol., 37, 621-636, doi:10.1002/joc.4728, 2017.

Moran, E. F.: Deforestation and land use in the Brazilian Amazon, Hum. Ecol., 21, 1-21, doi:10.1007/bf00890069, 1993.

Nepstad, D., McGrath, D., Stickler, C., Alencar, A., Azevedo, A., Swette, B., Bezerra, T., DiGiano, M., Shimada, J., da Motta, R. S., Armijo, E., Castello, L., Brando, P., Hansen, M. C., McGrath-Horn, M., Carvalho, O., and Hess, L.: Slowing Amazon deforestation through public policy and interventions in beef and soy supply chains, Science, 344, 1118-1123, doi:10.1126/science.1248525, 2014.

Nóbrega, R. S.: Impacts of Deforestation on Climate and Water Resources in Western Amazon, in: chap. 2, edited by: Moutinho, P., InTech, Rijeka, Croatia, 386 pp., doi:0.5772/1979, 2012.

Panday, P. K., Coe, M. T., Macedo, M. N., Lefebvre, P., and de Almeida Castanho, A.: Deforestation offsets water balance changes due to climate variability in the Xingu River in eastern Amazonia, J. Hydrol., 523, 822-829, 2015.

Poulter, B., Hattermann, F., Hawkins, E., Zaehle, S., Sitch, S., Restrepo-Coupe, N., Heyder, U., and Cramer, W.: Robust dynamics of Amazon dieback to climate change with perturbed ecosystem model parameters, Global Change Biol., 16, 24762495, 2010.

Raskin, P. D.: Global scenarios: background review for the Millennium Ecosystem Assessment, Ecosystems, 8, 133-142, 2005.

Rothacher, J.: Increases in water yield following clear-cut logging in the Pacific northwest, Water Resour. Res., 6, 653-658, doi:10.1029/wr006i002p00653, 1970.

Sansom, P. G., Stephenson, D. B., Ferro, C. A. T., Zappa, G., and Shaffrey, L.: Simple Uncertainty Frameworks for Selecting Weighting Schemes and Interpreting Multimodel Ensemble Climate Change Experiments, J. Climate, 26, 4017-4037, doi:10.1175/jcli-d-12-00462.1, 2013.

Sheffield, J., Goteti, G., and Wood, E.: Development of a 50-year high-resolution global dataset of meteorological forcings for land surface modeling, J. Climate, 19, 3088-3111, 2006.

Siqueira Júnior, J., Tomasella, J., and Rodriguez, D.: Impacts of future climatic and land cover changes on the hydrological regime of the Madeira River basin, Climatic Change, 129, 117-129, 2015 . 
Sitch, S., Smith, B., Prentice, I., Arneth, A., Bondeau, A., Cramer, W., Kaplan, J., Levis, S., Lucht, W., Sykes, M., Thonicke, K., and Venevsky, S.: Evaluation of ecosystem dynamics, plant geography and terrestrial carbon cycling in the LPJ dynamic global vegetation model, Global Change Biol., 9, 161-185, 2003.

Soares-Filho, B. S., Nepstad, D. C., Curran, L. M., Cerqueira, G. C., Garcia, R. A., Ramos, C. A., Voll, E., McDonald, A., Lefebvre, P., and Schlesinger, P.: Modelling conservation in the Amazon basin, Nature, 440, 520-523, 2006.

Song, X.-P., Huang, C., Saatchi, S. S., Hansen, M. C., and Townshend, J. R.: Annual Carbon Emissions from Deforestation in the Amazon Basin between 2000 and 2010, PLoS One, 10, e0126754, doi:10.1371/journal.pone.0126754, 2015.

Sorribas, M. V., Paiva, R. C., Melack, J. M., Bravo, J. M., Jones, C., Carvalho, L., Beighley, E., Forsberg, B., and Costa, M. H.: Projections of climate change effects on discharge and inundation in the Amazon basin, Climatic Change, 136, 555-570, 2016.

Sterling, S., Ducharne, A., and Polcher, J.: The impact of global land-cover change on the terrestrial water cycle, Nat. Clim. Change, 3, 385-390, doi:10.1038/nclimate1690, 2013.

Stickler, C. M., Coe, M. T., Costa, M. H., Nepstad, D. C., McGrath, D. G., Dias, L. C., Rodrigues, H. O., and Soares-Filho, B. S.: Dependence of hydropower energy generation on forests in the Amazon Basin at local and regional scales, P. Natl. Acad. Sci. USA, 110, 9601-9606, 2013.
Tejada, G., Dalla-Nora, E., Cordoba, D., Lafortezza, R., Ovando, A., Assis, T., and Aguiar, A. P.: Deforestation scenarios for the Bolivian lowlands, Environ. Res., 144, 49-63, doi:10.1016/j.envres.2015.10.010, 2015.

Torres, R. R. and Marengo, J. A.: Uncertainty assessments of climate change projections over South America, Theor. Appl. Climatol., 112, 253-272, 2013.

Vera, C., Silvestri, G., Liebmann, B., and González, P.: Climate change scenarios for seasonal precipitation in South America from IPCC-AR4 models, Geophys. Res. Lett., 33, L13707, doi:10.1029/2006GL025759, 2006.

Verburg, P. H., Soepboer, W., Veldkamp, A., Limpiada, R., Espaldon, V., and Mastura, S. S.: Modeling the spatial dynamics of regional land use: the CLUE-S model, Environ. Manage., 30, $391-$ 405, 2002.

Washington, W., Weatherly, J., Meehl, G., Semtner Jr., A., Bettge, T., Craig, A., Strand Jr., W., Arblaster, J., Wayland, V., James, R., and Zhang, Y.: Parallel climate model (PCM) control and transient simulations, Clim. Dynam., 16, 755-774, 2000.

Yip, S., Ferro, C. A. ., Stephenson, D. B., and Hawkins, E.: A Simple, Coherent Framework for Partitioning Uncertainty in Climate Predictions, J. Climate, 24, 4634-4643, doi:10.1175/2011jcli4085.1, 2011.

Zhang, K., Castanho, A. D., Galbraith, D. R., Moghim, S., Levine, N., Bras, R. L., Coe, M., Costa, M. H., Malhi, Y., Longo, M., Knox, R., McKnight, S., Wang, J., and Moorcroft, P. R.: The Fate of Amazonian Ecosystems over the Coming Century Arising from Changes in Climate, Atmospheric $\mathrm{CO}_{2}$ and Land-use, Global Change Biol., 21, 2569-2587, doi:10.1111/gcb.12903, 2015 . 